\title{
鉄筋のはらみ出しを考慮した場所打ち杭のモデル と地盤振動が杭基礎に与える影響評価への適用
}

\author{
白戸真大 ${ }^{1} \cdot$ 木村嘉富 $^{2} \cdot$ 福井次郎 ${ }^{3}$ \\ 1正会員 修 (工) 独立行政法人士木研究所 構造物研究グループ基礎チーム 研究員 (テ305-8516 茨城県つくば市南原 1-6) \\ 2正会員 工修 独立行政法人士木研究所 企画部研究企画課 課長 \\ 3正会員 工修 独立行政法人士木研究所 構造物研究グループ基整チーム 上席研究員
}

\begin{abstract}
場所打ち杭では，かぶりコンクリートのはく離，鉄筋のはらみ出しにより，耐力低下が生じることが実験から明 らかになってきている. そこで, 本論文では, 杭体をファイバー要素でモデル化することを前提に，はらみ出しを考 慮した鉄筋の構成則と，その構成則を用いる場合の要素長の設定法を提案する.ここに，はらみ出しは，鉄筋の塑性 座届としてモデル化する. 提案する構成則と要素長の設定方法を用いた有限要素解析は, 場所打ち杭の正負交番載荷 実験結果の耐力低下挙動を再現することができた. また, この構成則を用いて, 場所打ち杭基礎の地震時挙動を解析 し, 地中深部において杭基礎が損傷を受けた場合の杭基礎の挙動を把握し, 地盤の振動変位作用に対する杭基礎の耐 震設計法を検討した.
\end{abstract}

Key Words : pile foundation, post peak behavior, swelling out of re-bar, kinematic interaction, seismic design

\section{1. はじめに}

近年, 構造物の設計は, 耐震性などの性能に対する アカウンタビリティーを要求されるようになってきてい る. 構造物の設計基準も, 構造物に要求される性能を明 確にし, 性能を満足することを照査する, 性能照査型へ と移行している.

現在, 道路橋基礎の設計は, 橋の供用中に発生する確 率は低いが大きな強度を持つ地震動に対しては, 震後, 大規模な修復作業を行うことなく, 速やかに橋の供用を 確保できること, また, 基礎本体の損傷が修復可能な程 度であることを満足するような水平耐力および変形性能 を付与することを目標としている1),2)。そして，これら の要求性能の照査法として, 地震時保有水平耐力法を用 いており, 基礎に上部構造からの慣性力を作用させて設 計するものとしている.

上部構造からの慣性力による応答に対する杭頭部の損 傷と基礎の安定性に関しては, 筆者らは, 実験を行い, 上記の要求性能を満足するための基礎としての塑性率の 制限值を提案している2),3),4). 提案している制限值は, 所定の構造細目を満足することで, 杭本数・杭種に関わ らず一律の值としているが, 本来は, 使用する杭体のじ 几性や杭列数で変わるものである.これは, 現状の数值 解析モデルでは, 杭体の耐力低下挙動のモデル化が十分
ではないために, 各杭の損傷状態と, 基礎としての安定 との関係を十分には再現できないことから, 大規模な載 荷実験を行い, 実験で確認した範囲で提案しているため である.

また, 近年, 被災事例などから, 杭基礎は, 地首の硬 軟の境界付近で地盤の振動変位による損傷を受け易いこ とが明らかになってきており，設計実務に適用できるよ うな損傷の予測手法に関して精力的に研究が進められて (るる5),6),7),8),9),10). しかし，杭基礎は，地盤に支持され た, かつ複数の杭で構成される高次不静定構造物である ため, 地震時の地盤の振動変位により生じる地中深部で の杭体の局部的な損傷や耐力低下が基礎の安定に即座に 影響を与えるとは考えにくいものの，その影響度が明ら かになっておらず，耐震設計上の取り扱いも明確なもの になっていない.

したがって, 性能照査型の設計体系を確立するために は，慣性力に対する応答の照査の検討の際に行ったよう に, 基礎の地震時の挙動を把握し, 地中深部での杭体の 損傷状態と基礎の安定性に関して明らかにする必要があ る. しかし，この検討を実験により行うことは難しい． そこで, 任意の構造諸元および地盤条件の設定が可能 である数值解析による検討が有効であるが，上述のよう に, 杭体の耐力低下挙動を追跡できるモデルは十分では ない. 
杭には, その材質によりいくつかの種類があるが, 特 に，基礎の中で最も良く用いられる場所打ち杭基礎につ いて, 部材の耐力低下挙動が再現できるモデルの開発を することは, 基礎の耐震設計法の確立のために非常に有 意義である.

$\mathrm{RC}$ 部材の破壊の進行や最大耐力点以後の挙動につい てはすでに検討が進められており ${ }^{11)}$, モデル化や数值 解析手法に関して, 鉄筋のはらみ出しの考慮が必要なこ と12),13),14),15),16), また, 有限要素法において軟化する 構成則を用いるときには有限要素解の要素長依存性の問 題を考慮する必要があることが指摘されている17),18).

筆者らも, 気中において組杭および単杭の交番載荷実 験を行い, 耐力低下域に至るまでの杭基礎の損傷状況を 把握しており ${ }^{3), 4)}$, また, この実験結果に対して, 杭体 をファイバー要素でモデル化した有限要素解析も行って (る19). その結果, 杭基礎のように, 部材の非線形特性 が上部構造の水平変位に応じた杭体の軸力の変動により 変化する構造でも, 材料非線形性, および, 軸方向鉄筋 のはらみ出しを個々のファイバーに考慮することで, 基 礎としての耐力低下挙動を解析できることを示した。し かし，任意の配筋の場所打ち杭について，鉄筋のはらみ 出し特性を設定する方法や， はらみ出しに伴い軟化する 構成則を用いるときの要素長の設定方法の問題は, 未だ 解決されていない.

そこで，本論文では，まず，杭体のモデルにファイ バ一要素を用いることを前提として，場所打ち杭の弾性 挙動から耐力低下挙動までを一貫して解析するための軸 方向鉄筋の一軸の構成則と, それを適用する要素の要素 長の設定法を一つ提案する．提案する手法は，軸方向鉄 筋のはらみ出しを, かぶりコンクリートの圧壊・はく離 後に生じる塑性座届現象としてモデル化して, はらみ出 しを考慮していない鉄筋の構成則に足しあわせるもので ある. また, 塑性座屈長をファイバー要素長とすること で, 有限要素解の要素長依存性の発生を回避する. そし て, 提案モデルを用いて, 場所打ち杭の繰返し水平載荷 実験結果の解析を行い, 提案モデルの精度・特性を検証 する.

次に, 提案手法を用いて, 場所打ち杭基礎の地震時挙 動を把握するための動的解析を行い, 提案手法の動的解 析への適用性を確認するとともに, 解析結果より, 地中 深部で杭体に損傷をもたらす作用要因，および，地中深 部での杭体の損傷と基礎の安定の関係を明らかにするこ とを試みる. そして, 地震時の地盤の振動変位作用を考 慮した杭基礎の設計法に関して，考察を加える.

なお, 本論文では, 解析において, フーチングからの 杭の伸び出し分を考慮していない，これは，杭の伸び出 しに関しては，定量化を行うには実験データが十分では なかったこと, 杭基礎の耐力低下領域での挙動は, むし
ろ軸方向鉄筋のはらみ出しの影響に支配されると考えた ことによる. また，本論文では，杭体の曲げ耐力の低下 が基礎に与える影響を検討するものとし，せん断破壊に よる影響については今後の課題とする.

\section{2. 杭体ファイバーに用いる構成モデルとファ イバー要素長の設定}

\section{(1) はらみ出しのない鉄筋の構成則}

本論文では，基本となる軸方向鉄筋の構成則に，繰返 し載荷を受ける $\mathrm{RC}$ 部材の鉄筋の構成則として提案され た Menegotto-Pinto モデル20),21)を用いるものとした.

Menegotto-Pinto モデルは，図-1に示すように，初 期剛性 $E_{0}$ と降伏後剛性 $E_{1}$ のバイリニアモデルに漸近 する曲線で定義されるモデルであり, 次式で示される.

$$
\sigma^{*}=b \varepsilon^{*}+\frac{(1-b) \varepsilon^{*}}{\left(1+\varepsilon^{* R}\right)^{1 / R}}
$$

ここに,

$$
\sigma^{*} \equiv \frac{\sigma-\sigma_{r}}{\sigma_{0}-\sigma_{r}}, \quad \varepsilon^{*} \equiv \frac{\varepsilon-\varepsilon_{r}}{\varepsilon_{0}-\varepsilon_{r}}
$$

である. $\sigma$ は応力, $\varepsilon$ はひずみ, また, $\left(\sigma_{r}, \varepsilon_{r}\right),\left(\sigma_{0}\right.$, $\left.\varepsilon_{0}\right)$ は，それぞれ，図-1に示すように，ひずみが反転す る点 (反曲点) と, そこから初期剛性 $E_{0}$ で除荷・再載荷 された場合に包絡線と交わる点である. $b$ は，降伏後の 硬化率を表し, 初期剛性 $E_{0}$ と降伏後剛性 $E_{1}$ により,

$$
b \equiv E_{1} / E_{0}
$$

で定義される. また， $R$ は曲率パラメターで, 次式によ る.

$$
R=R_{0}-\frac{a_{1} \xi}{a_{2}+\xi}
$$

ここに, $R_{0}, a_{1}, a_{2}$ は材料定数と考えて良く, $R_{0}$ は初 期降伏時の曲率パラメターである. $R_{0}, a_{1}, a_{2}$ の值は, 筆者らは材料試験などにより決定する方法を持っていな かったため, 文献 ${ }^{19)}$ の場所打ち杭の解析と同じ值を用い た. $\xi$ は, 各載荷ステップごとに更新されるパラメター で, 図-1のように，次式で定義される.

$$
\xi \equiv\left|\varepsilon_{0}-\varepsilon_{r}{ }^{\prime}\right| / \varepsilon_{y}=\left|e_{0}-e_{r}{ }^{\prime}\right|
$$

ここに, $\varepsilon_{r}{ }^{\prime}$ は一回前の反曲点のひずみであり, 対応す る応力が $\sigma_{r}{ }^{\prime}$ である．また，図-1では，

$$
s \equiv \sigma / \sigma_{y}, \quad e \equiv \varepsilon / \varepsilon_{y}
$$

と定義した.ここに， $\sigma_{y} ， \varepsilon_{y}$ は，それぞれ初期降伏応 力と初期降伏ひずみである. 式 (4), (5) は, 載荷経路途 中で一時的に除荷, 再載荷が生じた場合であっても, 除 荷, 再載荷経路の反曲点を用いて同様に算定する. ただ し, 第一回目のひずみ反転後の $\xi$ は, 図-1中の $\xi_{0}$ のよ うに設定する. 

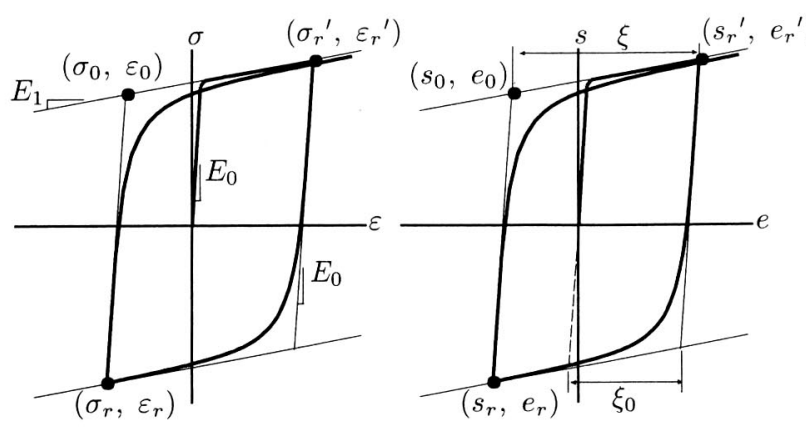

図-1 Menegotto-Pinto モデル

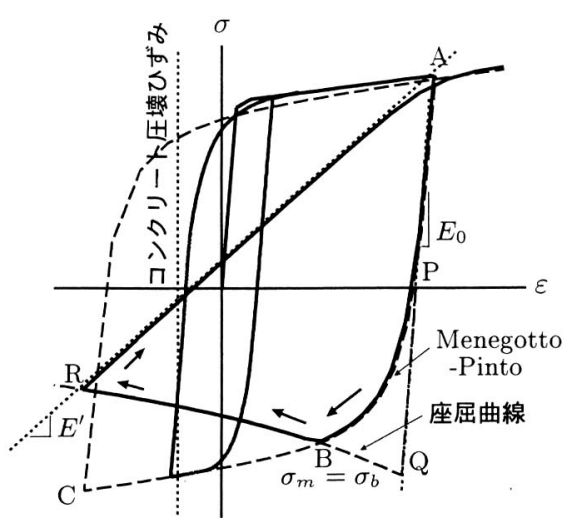

図-2 はらみ出しを考慮した鉄筋の応力－ひずみ関係

\section{（2）初期座屈発生の判定}

鉄筋のはらみ出しとかぶりコンクリートの破壊の間 に相互作用があることは十分に考えられる.たとえば, Suda ら ${ }^{12), 13)}$ は，様々な部材，配筋における鉄筋のはら み出しの発生の判定を一般化することを試み，鉄筋とか ぶりコンクリートの相互作用を考慮して鉄筋のはらみ出 しの発生を求める手法を提案している. しかし, 杭の載

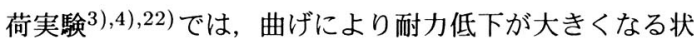
態では，かぶりコンクリートは，圧壊，もしくは，はく 離している．そこで，杭部材に関しては，軸方向鉄筋の はらみ出しは, 軸方向鉄筋位置のかぶりコンクリートが 圧壊するまでは生じないという, 単純なモデル化で十分 と考えた。

具体的には，履歷中で，鉄筋が，圧縮降伏後にかぶり コンクリートの圧壊ひずみを経験し，その後，除荷を受 け，再び圧縮載荷となるときから，はらみ出しを考慮 した構成則を適用した. したがって，単調載荷に対して は, 軸方向鉄筋のはらみ出しが生じないモデルとなって いる.

（3）はらみ出しを考慮した鉄筋の構成則と適用する ファイバー要素長の設定

軸方向鉄筋のはらみ出しを考慮した構成則として図一 2を提案する.これは, はらみ出しが生じていないと きの構成則である Menegotto-Pinto モデル (曲線 $\mathrm{ABC}$ ) をべースとし，それと軸方向鉄筋の塑性座屈曲線 (曲線 PQBR) で構成されるものである. ここに, 図-2の横軸 は，後述するように，配筋諸元より定まる軸方向鉄筋の 塑性座屈長で平均化されたひずみである.

塑性座屈曲線 PQBR は, 図-3に示すように, 带鉄筋 とコアコンクリートの拘束を受ける杭中の一本の軸方向 鉄筋に着目した, 二次元面内における塑性座屈解析によ り求める.ここに，带鉄筋による拘束は，带鉄筋間隔で 配置するバネで, コアコンクリート側へ軸方向鉄筋が変

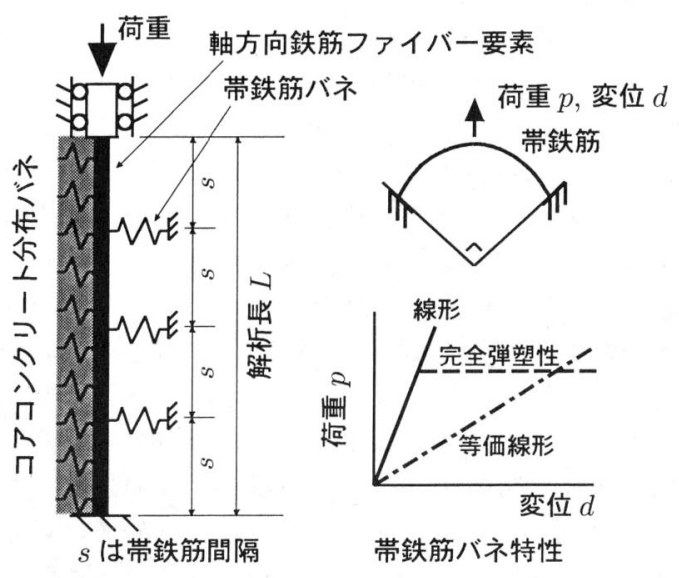

図-3 軸方向鉄筋の塑性座屈解析 ( $L=4 s$ の場合)

形しようとする際の拘束は, 分布バネでモデル化する. 境界条件は, 下端は完全固定, 上端は回転および水平変 位固定である.これらの塑性座屈解析モデルの詳細は,

3.で，塑性座屈解析結果とともに示す.

塑性座屈解析では, 解析長に依存して, 塑性座屈挙 動が変化することが予測される. 例えば, 文献12),13)で は, 帯鉄筋による拘束を弾性床でモデル化し, 軸方向鉄 筋の曲げ剛性に時々刻々の塑性化の度合いを考慮した值 を用いることで, 弾性座屈理論より座屈長を同定する 方法が提案されている. 本論文では, 塑性座屈解析を, 带鉄筋間隔 $s$ の $m$ 倍 ( $m$ は整数) の長さ $L=m s$ に対 して, $m$ に関して必要なケース数行い, 各 $m$ での挙動 を比較し, 最も荷重低下が大きな荷重 - 変位関係を取る $m=m_{0}$ の挙動を持って生じ得る塑性座屈挙動とするも のとした. ここに, 各 $m$ のケースにおいて, 帯鉄筋バネ は $(m-1)$ 個存在する. $m_{0}$ のケースにおける載荷点で の荷重 - 変位関倸を, 荷重を断面積で, 変位を塑性座屈 長 $L_{0}=m_{0} s$ でそれぞれ除すことにより, みかけの応力 
一ひずみ関係に直し, 座屈が発生しない状態の応力ーひ ずみ関係の圧縮側の経路に組込むものとする. 求めた塑 性座屈曲線の組込み方は, 文献16)を参考にし, 図-2の 曲線 PQBR のようにした. 図-2 の点 $\mathrm{P}$ は, 最大引張り ひずみ点 (図-2では点 $\mathrm{A}$ ) から初期勾配 $E_{0}$ で弾性除荷し たときに応力がゼロとなる点である. なお，後述の杭の 解析においては, 塑性座屈解析で得られる離散デー夕を 区間線形で補間して組み込んだ。

座屈は，同一ひずみに対し， Menegotto-Pinto モデ ルで得られる圧縮応力 $\sigma_{m}$ と塑性座屈曲線 PQBRより 得られる $\sigma_{b}$ を比較して, $\sigma_{m}=\sigma_{b}$ となったとき $(\mathrm{B}$ 点) に発生するものとし, Menegotto-Pinto モデルの BC で はなく, 塑性座屈曲線上の BR へ経路を変える.

座屈経路上から反転し, 引張り載荷を受けるときは, 筆者らが既に文献 ${ }^{19)}$ で提案しているように, 履歴中の最 大引張りひずみ点 $\mathrm{A}$ を目指すものとする.これは, 圧縮 側ではらみ出した軸方向鉄筋は, 再び伸びきるまでは, はらみ出しが発生していない状態よりも引張り力に対す る抵抗が小さいと考えて設定したものである. 後述の杭 の解析においては, Menegotto-Pinto モデルの $E_{0}$ を圧 縮側反曲点 $\mathrm{R}$ と履歷中の最大引張りひずみ点 $\mathrm{A}$ を結ぶ 直線の勾配 $E^{\prime}$ に, 履歴パラメター $R$ を $R=R_{0}$ とし た.

次に, この構成則を杭体ファイバー要素に適用する場 合の要素長の設定であるが, 曲線 PQBR の設定に用い た塑性座屈長 $L_{0}$ とする.これは, 変位を要素長で平均 化する操作により, 物理的な現象を要素長に反映させ ることを目的として提案するものである.これまでの載 荷実験結果 $3(, 4), 22)$ から, 通常の配筋では, 鉄筋のはらみ 出し長さは, 杭径の $1 / 2$ 倍程度になると予想され, この 程度の要素長であれば, 要素の一本のファイバーで引張 り・圧縮の両者が現れることはほとんどないと考えら れるので, このような操作は問題ないと考える. また, 有限要素法では, 離散化に対して精度を上げるために, 要素寸法を小さくして, 要素数を増やすことが行われる が, 一般に, 杭基礎は, 杭長が杭径の 10 倍以上である ため, 要素分割数が解析精度へ与える影響は少ないと考 えられる.

なお，ここではベースとなる構成則として Menegotto -Pinto モデルを用いたが, ここで提案したはらみ出しを 考慮した鉄筋の構成則は, 全ひずみ形式で記述される任 意の構成則をべースにすることができる.

\section{（4）コンクリートの構成則}

本論文では繰返し載荷を受ける杭基礎の耐力低下挙動 の解析を行うことを目的としているため, 綝返し載荷を 考慮し, かつ軟化域の挙動までモデル化されている Ristic ら ${ }^{21)}$ による修正六車モデルを用いることとした.

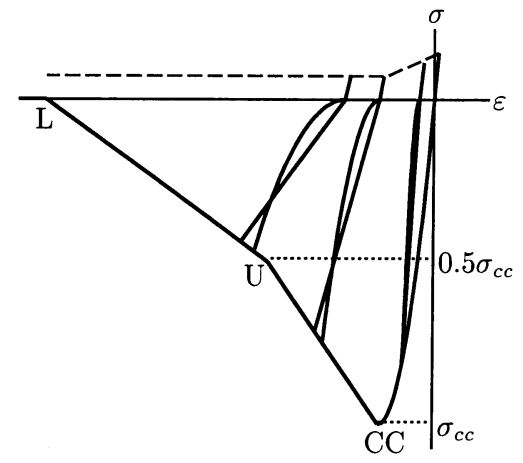

図-4 本論文で用いたコンクリート構成則の模式図

ただし，本論文では，以下の修正を行い，図-4のよう な骨格曲線とした. まず, 圧縮側の応力最大点 CC, お よび第一低下勾配 $(\mathrm{CC}-\mathrm{U})$ は, 帯鉄筋による横拘束効果 が考慮され，かつ，道路橋で使用される橋脚・杭程度の 帯鉄筋体積比の柱部材に対して Hoshikuma らが提案し ている道路橋示方書のモデル1),23)により算定した. した がって, 修正六車モデルの骨格曲線は, 最大応力の保持 領域がなくなる．また，道路橋示方書のモデルの低下公 配は, 複数の大型要素実験結果より, 最大応力 $\sigma_{c c}$ から $0.5 \sigma_{c c}$ の区間で同定されたものであるため ${ }^{23)}$, 軟化領域 の $0.5 \sigma_{c c}$ 以下では低下勾配を便宜的に $1 / 2$ とした.

ここで, コンクリートの構成則も軟化する構成則であ るため, 鉄筋においてひずみを塑性座屈長に対して平均 化していることと同様の配慮を, コンクリートに対して も行う必要がある.この問題を解決する手法は, 精力的 に研究が進められているが, 確立されたものはない14). 本論文では, 既往のコンクリートの応力 -ひずみ関係の 算出に用いられた基準長さは，一般に $20 \mathrm{~cm} \sim 30 \mathrm{~cm}$ 程 度を基準に求められていると考えられること，また，そ の場合, 一般の場所打ち杭の鉄筋のはらみ出し長さ (塑 性座屈長) と同じオーダーの長さであると考えられるこ とから, 骨格曲線には, 道路橋示方書のモデルをそのま ま適用することにした.

\section{3. 塑性座屈解析による鉄筋のはらみ出し特 性の把握}

\section{(1) 塑性座屈解析モデル}

図-3のコアコンクリートと帯鉄筋に拘束された軸方 向鉄筋の塑性座屈解析を, 二次元の有限要素法により行 う. 解析は, 有限変位解析であり,ここでは, 軸方向鉄 筋自体を断面方向に短冊状に分割したファイバー要素で モデル化する.

軸方向鉄筋ファイバー要素の各ファイバーの構成則に は, Menegotto-Pinto モデルを用いる.これは，座屈 
挙動を組み込むべースとなる鉄筋の構成則と整合が取 れると考えたためである、帯鉄筋バネのバネ定数は，こ こでは便宜的に，図-3に示すように，带鉄筋で作った開 角 $90^{\circ}$ の雨端固定アーチの頂部に, 外向き法線方向の荷 重を作用させた時の荷重 - 変位関係を, 別途解析し与え る.コアコンクリート分布バネは, 圧縮側はバネに変形 がほとんど生じないように十分大きなバネ定数を設定 し，引張りには抵抗しないように設定した.

ここでの解析では, 軸方向鉄筋は, 軸方向には各带 鉄筋間を 10 分割し，断面方向には 50 分割した.コアコ ンクリート分布バネは, 各要素節点に集約して配置し た．また，座屈が発生するよう，軸方向鉄筋中央位置で $L / 10000$ のたわみとなる放物線分布の初期不整を各節点 に与えた.

\section{（2）軸方向鉄筋のはらみ出し長さの同定}

解析対象は，4.で載荷実験の解析を行う模型場所打 ち杭 2 体である. 諸元は，それぞれ図-10，15に示さ れている. 本論文では, 前者の杭を模型杭 1 , 後者の杭 を模型杭 2 と呼ぶものとする. 解析に必要な材料定数 や Menegotto-Pinto モテルの履歴パラメターは，4.の 杭の載荷実験の解析に用いている值と同じ值を用いた.

ここでは，帯鉄筋は降伏しないものとして，帯鉄筋バ ネを設定した結果を示す. 求まったバネ定数は, 模型杭 1 は $k_{f}=1.7 \mathrm{MN} / \mathrm{m}$, 模型杭 2 は $k_{f}=19.0 \mathrm{MN} / \mathrm{m}$ であ る. また，コアコンクリート分布バネ定数には，十分に 大きな值として $9.8 \mathrm{GN} / \mathrm{m}^{2}$ を与えた。

2.(3)に記述したように, 塑性座屈解析を带鉄筋間隔 $s$ の $m$ 倍 ( $m$ は整数) の長さ $L=m s$ に対して行い, 各 $m$ での挙動を比較し, 最も不安定な荷重－変位関係を取る $m=m_{0}$ を求める.

模型杭 1 に関して, $L=1 \sim 6 s$ の 6 ケースの平均 ひずみ (= 軸方向変位 / 解析長 $L)$ が $5 \%$ の時の変形状態 が図-5である．図-5のスケールは，それぞれの解析長 $L$ で無次元化されており, 破線が初期形状, 実線が変形 後の形状である. 図中, バネの絵は概念図で, バネが二 重に見えるのは, これも変形前後の形状が描かれている ためである. 変形状態を比較すると $L=5 s, 6 s$ の時 は, $L=3 s$ の時上同じ座屈モードが生じているように 見える.

そこで, 座屈波 1 つあたりの荷重 - 変位関係を評価す るため, 載荷点での变位を座屈波の数で除したものと, 載荷荷重との関係について整理したものを図-6に示す. 座屈は材料の降伏直後に発生し，その後は，图-5で同じ 座屈モードであると考えられた $L=3 s, 5 s, 6 s$ がほぼ同 様の挙動を示し, 最も荷重低下が大きい. 写真-1に示す ように, ここで解析対象とした杭の載荷実験において軸 方向鉄筋がはらみ出した長さは $3 s$ 程度であり, 本解析

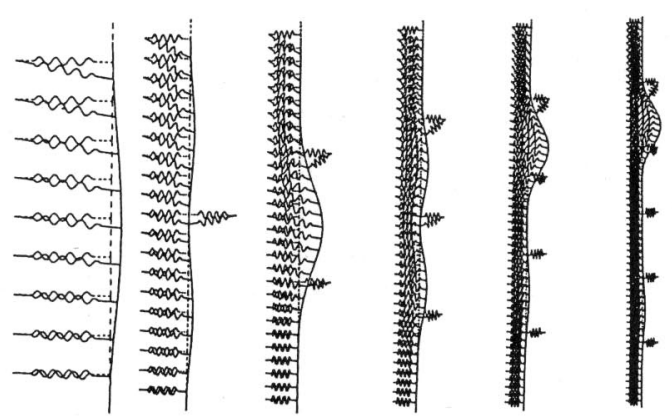

$L / s=1 L / s=2 L / s=3 L / s=4 \quad L / s=5 \quad L / s=6$

图-5 軸方向鉄筋の塑性座届モード

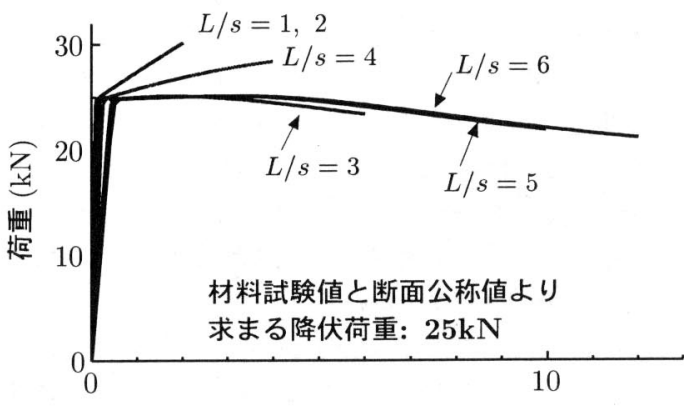

変位 / 座屈波形の個数 $(\mathrm{mm})$

图-6 座屈波 1 つあたりの荷重 - 変位関係 (模型杭 1)
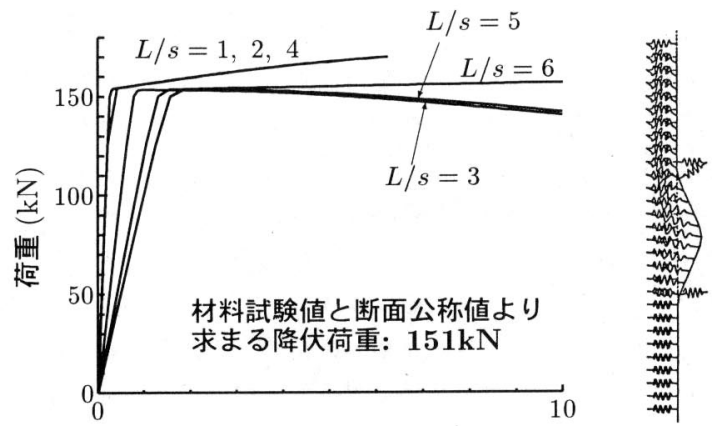

変位 / 座屈波形の個数 $(\mathrm{mm})$

図-7 座届波 1 つあたりの荷重 - 変位関係と $L=3 s$ の塑性座 屈変形 (模型杭 2)

で最も不安定なモードを示す $3 s$ に一致する.

同様に, 模型杭 2 の軸方向鉄筋に関して, 塑性座屈解 析を行い，整理したものが図-7である.ここに， $L=$ $3 s$ の座屈波形も併せて示す．写真-2 と比較すると， $L=$ $3 s$ のときの座屈形状は, 実験でのはらみ出し形状とほぼ 同じ形状であることがわかる. また， $L=5 s$ の時も， $L=3 \mathrm{~s}$ と同様の座屈波が 1 つ発生していた．このよう に, 模型杭 $1 ， 2$ で配筋が異なっているが，座屈後の軸 
力の低下が最も著しい座屈モ一ドは, それぞれ唯一に定 まっており，実験で観察されたはらみ出し形状に近い形 状となる。

以上をまとめると, 軸方向鉄筋の塑性座屈は, 断面の 塑性化による曲げ剛性の低下により生じるため, 塑性座 屈荷重は，解析長 $L$ によらず一定となるが，一方，座屈 モードや座屈後の荷重低下経路は, 解析長 $L$ により異な り, 実際の軸方向鉄筋のはらみ出し現象としては, 杭体 の配筋から決まる最も不安定なモードが生じていること が予測される.

\section{（3）帯鉄筋バネの剛性の違いによる挙動の比較}

(2)の塑性座屈解析では, 帯鉄筋は, 弾性領域にある と仮定してきたが, 杭の変形に伴い鉄筋のはらみ出しが 大きくなると, 塑性化することも考えられる. そこで, 帯鉄筋バネの剛性が, 軸方向鉄筋の荷重 - 変位関係に及 ぼす影響を把握するため, 解析長を $L=3 s$ と一定に し，以下の三種類の帯鉄筋バネを用いた解析を行った.

・帯鉄筋バネを弾性バネとした場合 ((2)に同じ).

- 帯鉄筋アーチの最外縁が降伏応力に達した点を降伏 点とした完全弾塑性型バネとした場合.

・ 軸方向鉄筋の圧縮量が $0.1 L$ に達した時の完全弾塑 性型バネの変形量に対応する割線バネ剛性 $k_{f e}$ を求 め, 模型杭 1 はバネ定数 $k_{f e}=k_{f} / 3$, 模型杭 2 は $k_{f e}=k_{f} / 1.4$ の等価線形バネとした場合.

ここに，等価線形バネは，帯鉄筋バネの評価法が便宜的 なものであることから, 解析結果が杭体の耐力を過大評 価することがないように, 耐力低下後のある損傷状態を 目標に, 安全側の設定となることを意図して設定したも のである.

模型杭 1 の解析結果を図-8に示す. 模型杭 1 の軸方向 鉄筋之帯鉄筋の組み合わせでは，帯鉄筋の剛性により塑 性座屈後の挙動に差が出る結果となった. 一方, 模型杭 2 の解析結果を図-9に示すが, 模型杭 2 の配筋では, 軸 方向鉄筋の塑性座屈後挙動に帯鉄筋の剛性による違いは 明確ではなかった，模型杭 1 で見られた，帯鉄筋バネの 違いに起因する軸方向鉄筋の塑性座屈後挙動の違いが杭 体の挙動に与える影響は，4.で検討する.

その他, 鉄筋のはらみ出し挙動は, 軸方向鉄筋の硬化 率等にも依存することを確認している．詳細は文献24)を 参照されたい.

\section{4. 模型場所打ち杭の水平交番載荷実験に対 する数値解析}

実験結果を提案モデルにより解析し, 提案モデルの妥 当性を検証する.ここで解析対象とするのは, 曲げ損傷 による鉄筋のはらみ出しが生じた, 模型場所打ち杭の水

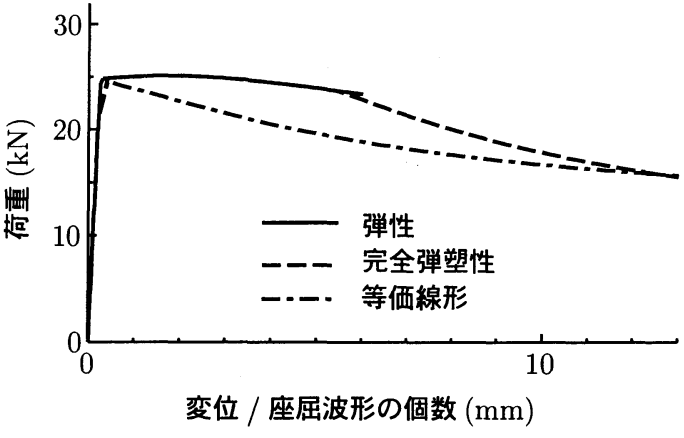

図-8 帯鉄筋バネ剛性の違いによる座屈波 1 つあたりの荷重 変位関係 (模型杭 $1, L=3 s$ の場合)

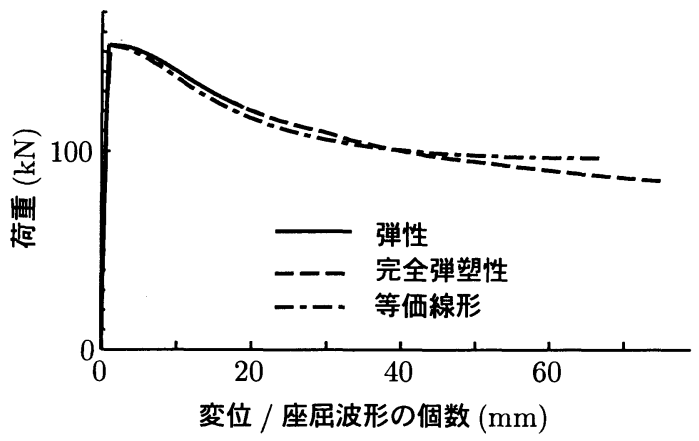

図-9 帯鉄筋バネ剛性の違いによる座届波 1 つあたりの荷重 変位関係 (模型杭 $2, L=3 s$ の場合)

平交番載荷実験 2 ケースである. いずれのケースの模型 杭も, 実際の場所打ち杭と同等の鉄筋比のもので, 比較 的大型のものである.

この 4.での解析は, 微小変位理論の枠内で, 二次元の 有限要素法により行う. 杭体をモデル化するファイバー 要素では，軸方向鉄筋は，おのおのを一本のファイバー としてモデル化し，また，コンクリート断面は，断面方 向に 50 分割したのち, かぶりコンクリートとコアコン クリートに分割した。

\section{（1）模型杭 1 の一定軸力下での水平交番載荷実験}

\section{a) 実験概要と解析モデル}

ここで解析するのは, 筆者らが行った模型場所打ち杭 の水平交番載荷実験 4$)$ である. 模型杭 1 の諸元と実験概 要を図-10に，材料試験結果を表-1に示す．載荷は，鈶 直力 $147 \mathrm{kN}$ をまず載荷し, その後, 鈶直力を一定に保 ちながら水平変位を与える. 水平変位は, 杭体最外緑鉄 筋が降伏するときの変位を $1 \delta_{y}=3.57 \mathrm{~mm}$ とした $\pm n \delta_{y}$ $(n=1,2,3, \cdots, 16)$ の振幅で, 各 3 サイクルの繰返しを するものである.

載荷点での水平荷重 - 水平変位関係を図-11に示す. 


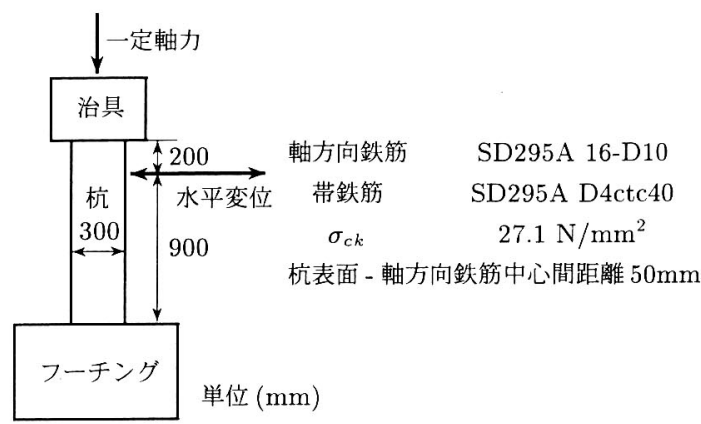

図-10 模型杭 1 の水平交番載荷実験

表-1 模型杭 1 の材料試験結果 鉄筋引張り試験

\begin{tabular}{|c|c|c|c|}
\hline 種類 & $\begin{array}{c}\text { 降伏応力 } \\
\left(\mathrm{N} / \mathrm{mm}^{2}\right)\end{array}$ & $\begin{array}{c}\text { 引張り強度 } \\
\left(\mathrm{N} / \mathrm{mm}^{2}\right)\end{array}$ & $\begin{array}{c}\text { 弾性係数 } \\
\left(\mathrm{kN} / \mathrm{mm}^{2}\right)\end{array}$ \\
\hline 軸方向鉄筋 & 348 & 478 & 175 \\
\hline 帯鉄筋 & 389 & 554 & 213 \\
\hline
\end{tabular}

\begin{tabular}{|c|c|c|c|}
\hline $\begin{array}{l}\text { 材齢 } \\
\text { (日) }\end{array}$ & $\begin{array}{l}\text { 圧縮強度 } \\
\left(\mathrm{N} / \mathrm{mm}^{2}\right)\end{array}$ & $\begin{array}{c}\text { 弾性係数 } \\
\left(\mathrm{kN} / \mathrm{mm}^{2}\right)\end{array}$ & $\begin{array}{l}\text { 割裂強度 } \\
\left(\mathrm{N} / \mathrm{mm}^{2}\right)\end{array}$ \\
\hline 40 & 27.1 & 26.5 & 2.72 \\
\hline
\end{tabular}

実験経過を簡単にまとめると，まず，水平荷重が $24.5 \mathrm{kN}$ に達したときに杭体にひび割れが発生し， $4 \delta_{y}(14.3 \mathrm{~mm})$ で最大水平荷重 $55 \mathrm{kN}$ に達した。 $5 \delta_{y}$ 載荷時に杭体と フーチングの境界部で杭体表面コンクリートが圧壊し た. $7 \delta_{y}(25.0 \mathrm{~mm})$ で荷重が若干低下するが, $7 \delta_{y}$ 〜 $10 \delta_{y}$ で荷重が保持された. しかし, $10 \delta_{y}(35.7 \mathrm{~mm})$ か ら再び荷重低下が始まり， $12 \delta_{y}(42.8 \mathrm{~mm})$ から杭体の損

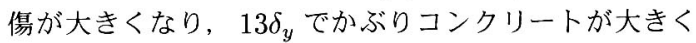
はく離した. その後, $14 \delta_{y}$ から軸方向鉄筋の破断が発 生し始め, $16 \delta_{y}(57.1 \mathrm{~mm})$ で実験を終了した，実駼終了 後の基部の損傷状況は，写真-1に示すように，鉄筋が， 帯鉄筋間隔の 3 倍 $(120 \mathrm{~mm})$ 程度の長さで, 正弦一波の 形状ではらみ出していた.

解析モデルは, フーチング結合部を固定端とした片持 ちばりである. 要素長は, 3.(2)の検討に基づき, 最も 不安定な座屈モードが生じたものの中で最短の $3 s$ (120 $\mathrm{mm})$ とする. 最短のものを用いたのは, 要素分割をで きる限り小さくして，節点自由度を多くしょうとした ためである. 軸方向鉄筋ファイバーに組込む塑性座屈曲 線は，図-8の，帯鉄筋バネを等価線形バネとした場合 と, 完全弾塑性型とした場合の 2 ケースを行った. 軸方 向鉄筋ファイバーのパラメターは, 断面量には JIS 公称 值を, 必要な材料定数には試駼值を用いた。 ただし, 降 伏後剛性は, 材料試験結果がなかったので, 模型杭 2 の

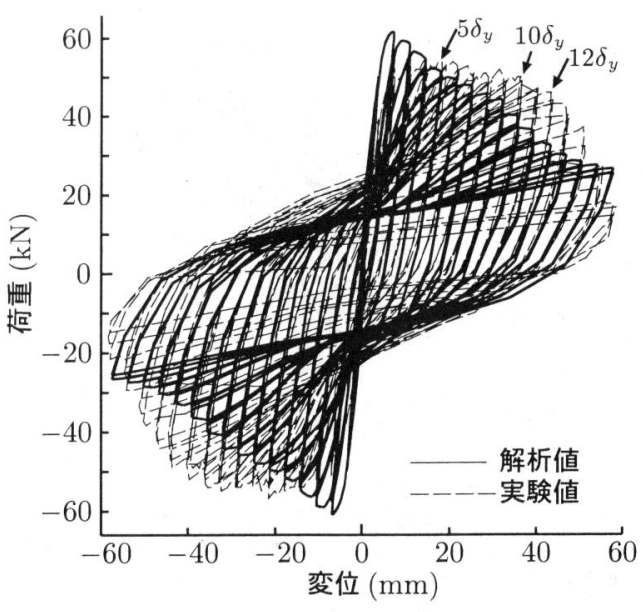

図-11 載荷点での水平荷重 - 水平変位関係 (模型杭 1)

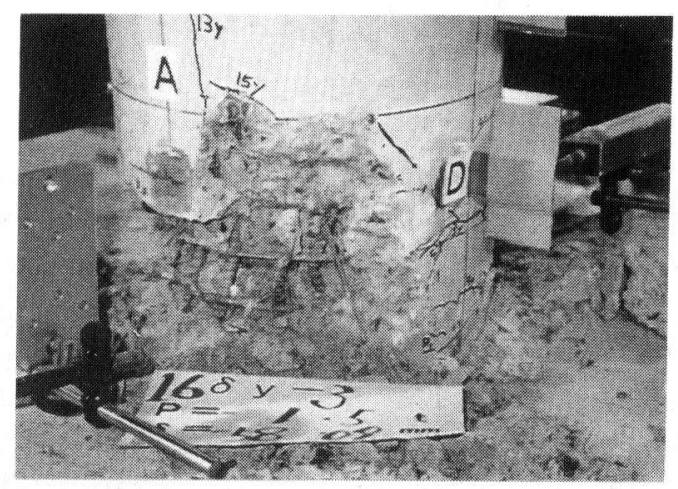

写真-1 模型杭 1 載荷実験終了後の基部の損傷状沉

軸方向鉄筋 (SD345) の引張り試験結果を参考に, 初期剛 性の $1 / 100$ とした.

また, かぶりコンクリートのパラメターは, 筆者らが 文献19)において鉄筋のはらみ出しを考虑せずに模型杭 1 を解析した際に，実験では大きく耐力が低下し始める $10 \delta_{y}$ 程度までを比較的精度良く解析できたバラメターを 用いた，帯鉄筋の拘束効果は考虑しておらず，第一低下 勾配はコアコンクリートの第一低下勾配の 1.5 倍となつ ている.ここでの要素長と文献 ${ }^{19)}$ の要素長が $20 \%$ 程度 異なることから，この值を用いることに問題があるかも しれないことは, 2.(4)のコンクリートの構成則のとこ ろで述べたとおりである.

解析手順は, まず, 頂部に所定の鈶直力 $147 \mathrm{kN}$ を載 荷し, その後, 鈆直力を保持したまま水平変位載荷位置 にて水平変位履歷を与えた.

\section{b) 解析結果および考察}

まず，耐力低下挙動が再現できるかどうかを確認する ために, 軸方向鉄筋の塑性座屈曲線として, 図-8で鉄筋 の降伏に伴い即座に荷重低下が生じる結果となった, 帯 


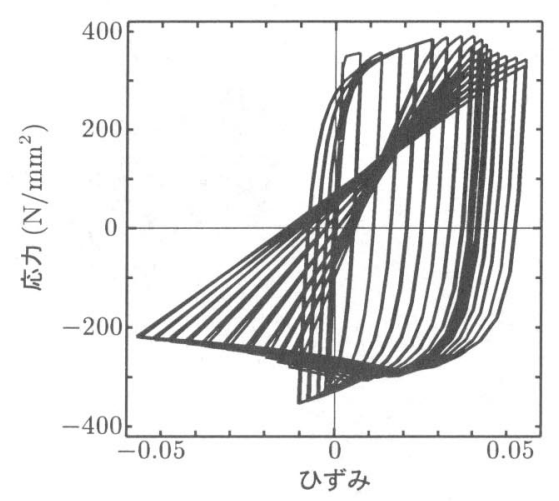

図-12 基部最外縁鉄筋の応力ーひずみ関係

鉄筋バネを等価線形バネとした場合の塑性座屈曲線を用 いた解析結果を示す．載荷点での水平荷重 - 水平变位関 係を, 実験結果とともに図-11に示す.

解析は, $4 \delta_{y}$ までは実験結果に比べて荷重を過大評価 する. その後, $6 \delta_{y}$ で基部要素の最外縁鉄筋ではらみ出 しが生じたことに伴い，実験よりも早い載荷段階からで はあるが，実験の $10 \sim 13 \delta_{y}$ で見られるものと同様の耐 力低下挙動が見られる.

図-12は，基部要素中心位置における最外縁鉄筋の応 力ーひずみ履歴である. $6 \delta_{y}$ からはらみ出しが生じ, 杭 の変形が大きくなるにしたがい引張り側でも各 $\delta_{y}$ での 応力が低下していく．これは, 鉄筋に残留のはらみ出し が蓄積していく過程を表すものであり, 実験終了時の写 真-1に一致する. また，鉄筋に生じる最大ひずみと最小 ひずみの差は $10 \%$ 程度であり, 鉄筋の座屈軟化曲線を 算定した際に，帯鉄筋バネを等価線形化した範囲内と考 えてよい.

比較のため,この実験に関して，鉄笳のはらみ出しを 考慮せずに解析した結果を図-13に示す，ただし，要素 長は, 文献 ${ }^{19)}$ と同じく, 杭径の $1 / 2(150 \mathrm{~mm})$ としてい る. 鉄筋のはらみ出しが生じないことと要素長が異なる ことを除けば，図-11の場合と解析条件は同一であるた め, 解析は, $4 \delta_{y}$ までは実験結果に比べて荷重を過大評 価する. それ以後は, 荷重 - 変位関係だけをみると $10 \delta_{y}$ までは比較的一致する。これは, 前述のように, 用いた

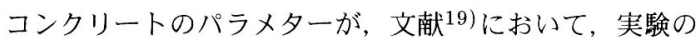
水平荷重 - 水平変位関係にのみ着目し, $10 \delta_{y}$ 程度まで 精度良く算定できるように試行錯誤して設定したものだ からである. しかし, 解析では, 実験において $10 \delta_{y}$ か ら耐力低下の度合いが大きくなる現象が再現できておら ず, $10 \delta_{y}$ 以後, 耐力を過大評価している. 荷重保持領 域から耐力低下域への移行を再現するには, コンクリー トの解析パラメターを制御するだけでは十分ではなく, 提案モデルのように鉄筋のはらみ出しを考慮することが

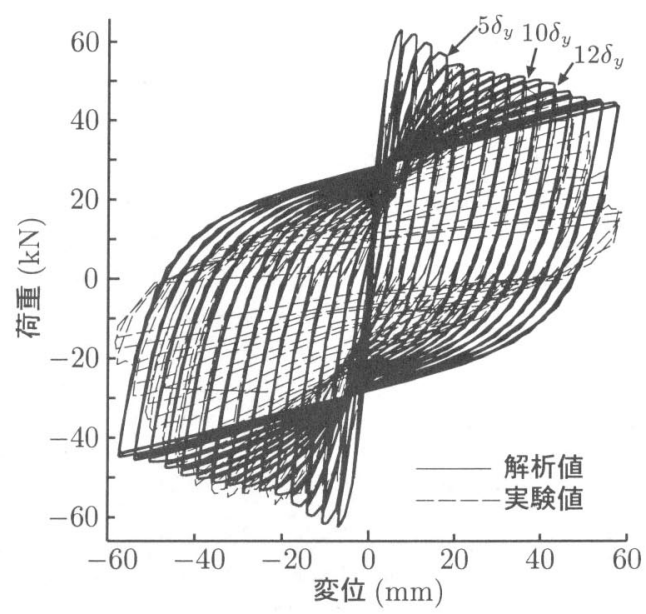

図-13 鉄筋のはらみ出しを考慮しない場合の載荷点での水平 荷重 - 水平変位関係 (模型杭 1)

必要であると考えられる.

以上より, 場所打ち杭の耐力低下域までの挙動と損 傷状態を数值解析により再現するためには, 提案モデ ルのように, 軸方向鉄筋のはらみ出し特性を考慮するこ とが有効であることがわかる.ただし, 定量的には, 解 析は, $4 \delta_{y}$ までは実験值より大きな荷重を算出し, その 後は, 耐力低下が早い載荷段階 $\left(6 \delta_{y}\right.$ 程度) から起きてお り, 荷重を小さく算出しているという問題がある.

解析が, 実験に比べ, 初期に荷重を過大評価し, そ の後, 荷重を低く評価する原因は, 主に, かぶりコンク リート構成則の骨格曲線にあると考えられる. ヤング率 や最大応力点が初期の荷重や最大耐力に影響を与えてい るとともに, その圧壊を軸方向鉄筋の座屈発生条件とし てモデル化しているため, 軟化勾配が耐力低下の発生に 大きく影響を与えていると考えられる.

解析では, 基部での最外縁軸方向鉄筋位置でのコン クリートの圧壊は, かぶりコンクリートでは $5 \delta_{y}$ 載荷 時, コアコンクリートでは $10 \delta_{y}$ 載荷時に発生している のに対し，実験では $5 \delta_{y}$ では基部表面のごく一部が圧壊 したにすぎず，かぶりコンクリートの損傷が大きくな るのは, $12 \delta_{y}$ 程度からであった. それに応じて, 解析 では，基部最外縁鉄筋の座屈発生は，図-12に示すよう に， $6 \delta_{y}$ と，実験ではまだかぶりコンクリートによる拘 束が存在していた載荷段階から発生している.

このことは，図-14からも考察できる。図-14は, 解 析による $13 \delta_{y}$ 終了後の各ファイバーの損傷状態である. 軸方向のコンクリートの圧壊領域および鉄筋の座屈が生 じている領域は, 基部の一要素, すなわち基部より帯鉄 筋間隔の 3 倍の領域 $(120 \mathrm{~mm})$ のみであり, 写真-1に示 す実験終了後の杭の損傷領域に一致する. しかし, コン クリートの断面方向の損傷の進展は異なり，写真-1では 


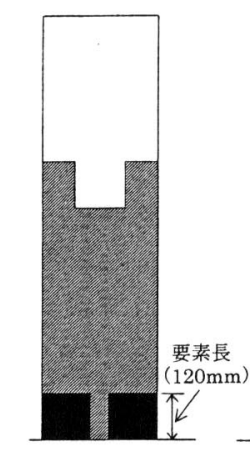

かぶり

グレー:ひびわれ

黒: 圧壊

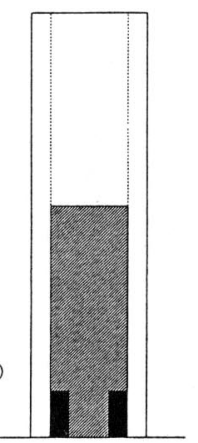

$コ ア$

ー:ひびわれ

黒: 圧壊

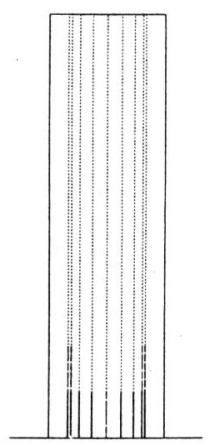

鉄筋

破線 : 降伏 実線 : 座屈
図-14 解析における $13 \delta_{y}$ 終了後の損傷状態

軸方向鉄筋位置の外側までしか大きな損傷は生じてい ないのに対し, 図-14では軸方向鉄筋位置よりも内部の コアコンクリートまで損傷が伸展しており，それに応じ $\tau$, 最終的に, 軸方向鉄筋の座屈が断面中央以外の鉄筋 で発生している. すなわち, 解析は, 損傷を過大評価し ている.

ここで, 鉄筋の塑性座屈曲線が解析結果に与える影響 を把握するために, 図-8の帯鉄筋バネを完全弾塑性型バ ネとした場合の結果を用いて解析を行ってみたが，各 $\delta_{y}$ での荷重が等価線形バネを用いた図-11の結果に比べて 数％大きい程度で, 全体的にほとんど変わらなかった. このように, 杭体の耐力低下挙動に与える帯鉄筋バネの 設定の影響は, かぶりコンクリートのモデル化の影響が 大きいためか顕著とならなかった。

\section{（2）模型杭 2 の軸力変動を伴う水平交番載荷実験}

\section{a) 実験概要と解析モデル}

解析対象は, 文献 25$)$ の模型場所打ち杭の正負交番載 荷実験である. 実験概要および材料試験結果を図 -15, 表-2に示す. 道路橋の場所打ち杭の杭径の使用頻度は, $\phi 1000, \phi 1200$ の二種類で全体の 8 割を越えること ${ }^{26)}$ 考えると, この模型杭は, 大型のものと言える. また, この実験では, 図-16に破線で示すように, 群杭基礎に おいて地震時に想定される荷重状態を模して, 水平力に 応じて変動する軸力を載荷している. 水平載荷は, 変位 制御により行われ，部材の変形角が $1 / 1000,1 / 400$ の 振幅で各 1 サイクル，1/200，2/200，4/200，6/200, $8 / 200,10 / 200$ の振幅で各 3 サイクルの繰返し載荷を与 えている.ここに, 部材の変形角とは, 載荷点における 水平変位量をせん断スパン長で除した值である.

試験終了後の損傷状態を写真-2に示す．軸方向鉄筋 は，帯鉄笳間で大きくはらみ出しているが，その二本の

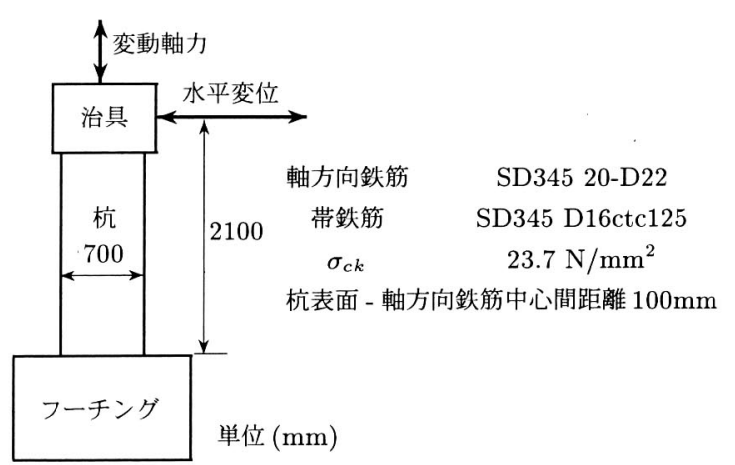

図-15 模型杭 2 の水平交番実験試験 ${ }^{25)}$

表-2 模型杭 2 の材料試験結果 鉄筋引張り試験

\begin{tabular}{|c|c|c|c|c|}
\hline 種類 & $\begin{array}{c}\text { 降伏応力 } \\
\left(\mathrm{N} / \mathrm{mm}^{2}\right)\end{array}$ & $\begin{array}{c}\text { 引張り強度 } \\
\left(\mathrm{N} / \mathrm{mm}^{2}\right)\end{array}$ & $\begin{array}{c}\text { 弹性倸数 } \\
\left(\mathrm{kN} / \mathrm{mm}^{2}\right)\end{array}$ & $\begin{array}{c}\text { のび } \\
(\%)\end{array}$ \\
\hline 軸方向鉄篮 & 397 & 589 & 195 & 23.2 \\
\hline 带鉄篎 & 397 & 569 & 189 & 22.8 \\
\hline
\end{tabular}

\begin{tabular}{|c|c|c|c|}
\hline \multicolumn{4}{|c|}{ コンクリート材料試験 } \\
\hline $\begin{array}{l}\text { 材齢 } \\
\text { (日) }\end{array}$ & $\begin{array}{c}\text { 圧縮強度 } \\
\left(\mathrm{N} / \mathrm{mm}^{2}\right)\end{array}$ & $\begin{array}{c}\text { 弾性係数 } \\
\left(\mathrm{kN} / \mathrm{mm}^{2}\right)\end{array}$ & $\begin{array}{c}\text { 割裂強度 } \\
\left(\mathrm{N} / \mathrm{mm}^{2}\right)\end{array}$ \\
\hline 10 & 23.7 & 21.9 & 2.4 \\
\hline
\end{tabular}

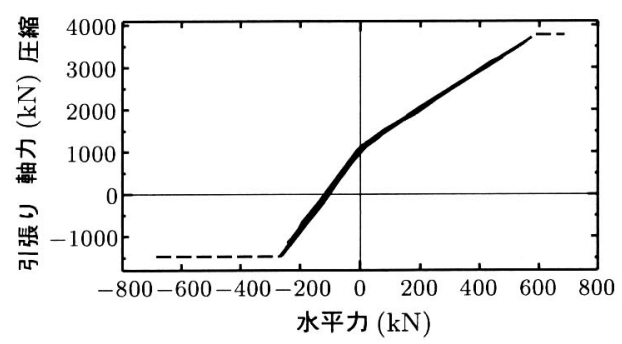

図-16 軸力変動のパターン $(\text { 圧縮が正 })^{25)}$ : 解析結果が実線

帯鉄筋も, 若干はらみ出している. 図-17には, 載荷点 における水平変位 - 水平荷重関係を示す. 実験経過を簡 単にまとめると, 圧縮軸力が增加する方向に $2 / 200$ の変 形角が増加した時点で圧縮側基部のかぶりコンクリート が圧壊，また，逆方向に同じ変位まで載荷した時点で圧 縮から引張りに移行した軸方向鉄筋が降伏し，圧縮側 では基部かぶりコンクリートの圧壊が生じる，そして， 圧縮軸力が增加する方向に変形角が $4 / 200$ に達したと きに引張り側の軸方向鉄筋が降伏する. その後, 变形角 6/200に至ったときに帯鉄筋も降伏する．最終ステップ である $10 / 200$ の圧縮軸力から引張り軸力となる載荷時 に，引張りを受ける軸方向鉄筋が破断している.

解析モデルは, 模型杭 1 の解析と同様に, フーチング 結合部を固定端とした片持ちばりであり, 杭体の要素分 


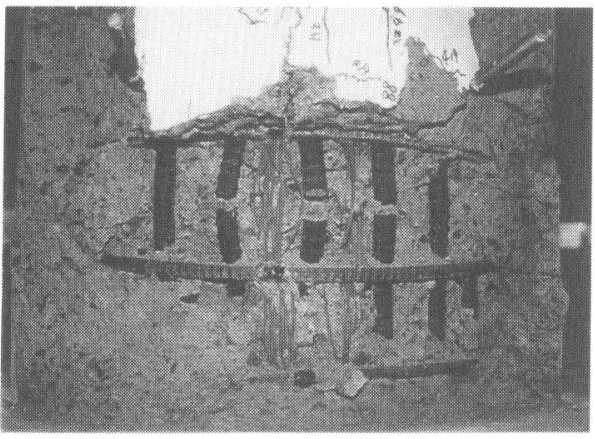

写真-2 模型杭 2 載荷実験終了後の基部の損傷状況 (圧縮軸力 時に曲げ圧縮となる面)

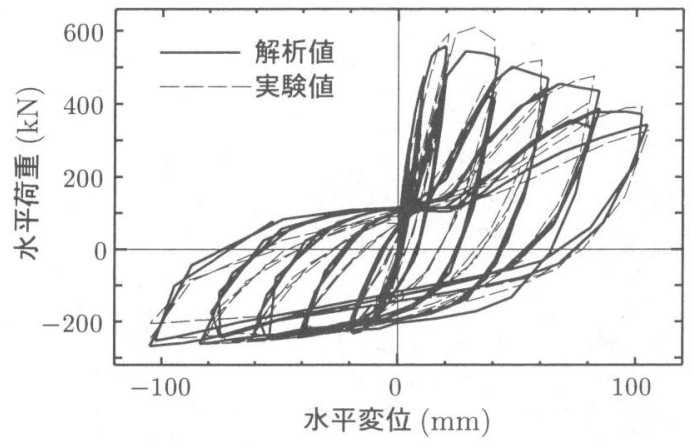

図-17 載荷点における水平変位 - 水平荷重関係 (模型杭 2)

割長は，図-7の結果に基づき，帯鉄筋間隔の 3 倍 $(3 s=$ $375 \mathrm{~mm})$ とする.

軸方向鉄筋ファイバーの各パラメターの設定は，模型 杭 1 と同様に設定した．ここに，軸方向鉄筋の降伏後剛 性は, 材料試験結果より, 降伏点と破断点を結ぶ線を参 考に，オーダーが合うように初期剛性の 1/100 とした。 また，塑性座屈曲線は，図一9の帯鉄筋バネを等価線形バ ネとした場合の結果を用いた．图一-9から分かるように， この杭体の配筋では，塑性座屈曲線は，帯鉄筋バネのモ デル化にはほとんど依存しない，かぶりコンクリートの 構成則は，便宜的に模型杭 1 の解析とした.

\section{b) 解析結果と考察}

解析では，水平変位履歴と軸力履歴を入力した，入力 軸力は, 解析で得られた水平反力に応じて，図-16に破 線で示した軸力を入力するのがよいが，ここでは汎用 コードにより解析を行ったため，そのような設定ができ なかった，そこで，実験の軸力履歴を初期値にした解析 を行い，それを基に軸力履歴を試行錯誤的に何度か変更 することで設定した．ここに，解析で得られた水平反力 一入力軸力の関係を図-16にあわせて示した.

水平変位載荷点における荷重 - 変位関係を図-17に示 す. 図-17は, 変動軸力のため原点に対して非対称な形 状を描いており, 解析結果と実駼結果は, 包絡線, 履歴
かぶり グレー:ひびわれ 黒: 压壊

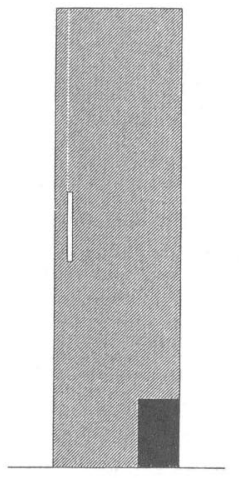

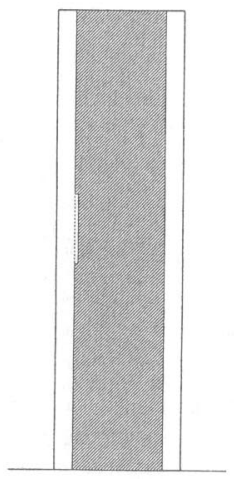

コア

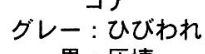

黒: 圧壊

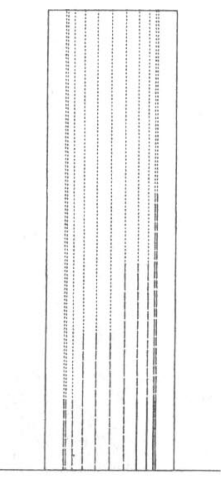

鉄筋 破線：降伏 実線 : 座屈
図-18 解析における全載荷終了後の損傷状態

ループ形状とも良く一致している．ここで, 最終載荷ス テップの負の載荷側で耐力を過大評価しているが，これ は, 実験では最終載荷ステップの引張り軸力を伴う載荷 時に鉄筋の破断が生じたのに対し，解析では破断に関し てモデル化を行っていないためと考えられる.

図-18に，解析における部材回転角 10/200 載荷後の 損傷状態を示す，軸力の変動は，図の右側に載荷すると きに軸圧縮力が増し, 図の左側に載荷するときに引張り 力が增す．解析結果は, 写真 -2 の実験結果之同様に, 損 傷状態が左右非対称となっており, 変動軸力の影響を反 映できていることが分かる．また，軸方向の損傷域は， 実験の方が若干大きいものの, 基部断面方向の損傷は, 実験, 解析ともにかぶりコンクリートのはく離, 圧壊と なっており，精度良く損傷状態を再現できている。

また, 基部付近の断面方向の損傷の伸展を比較してみ ると, 解析では変形角 $6 / 200$ 載荷時に基部要素の軸方向 鉄筋位置のかぶりコンクリートの圧壊が生じ， $8 / 200$ 載 荷時に塑性座屈が発生したのに対して, 実験では $6 / 200$ で帯鉄筋の降伏が確認されており，これは，軸方向鉄筋 位置のかぶりコンクリートに大きな損傷が生じたものと 判断できることから, 損傷の進展状況も一致している. このケースでは, かぶりコンクリートの破壊の進展が実 験結果と良く一致していたため, 載荷初期段階から耐力 低下領域の挙動までを再現できたものと考えられ，ここ からも, かぶりコンクリートのモデル化が, 今後の課題 であると言える.

以上のように, 模型杭 1,2 の載荷実験の解析結果は, 提案した手法が, 個々の杭体の諸元を反映させて解析を 行うことができる手法であること, また, 定量的な精度 に関しては不十分な場合もあるが，場所打ち杭の挙動お よび損傷過程を弾性域から耐力低下域まで統一的に追跡 するための有力な手法になり得ることを示している. 今 

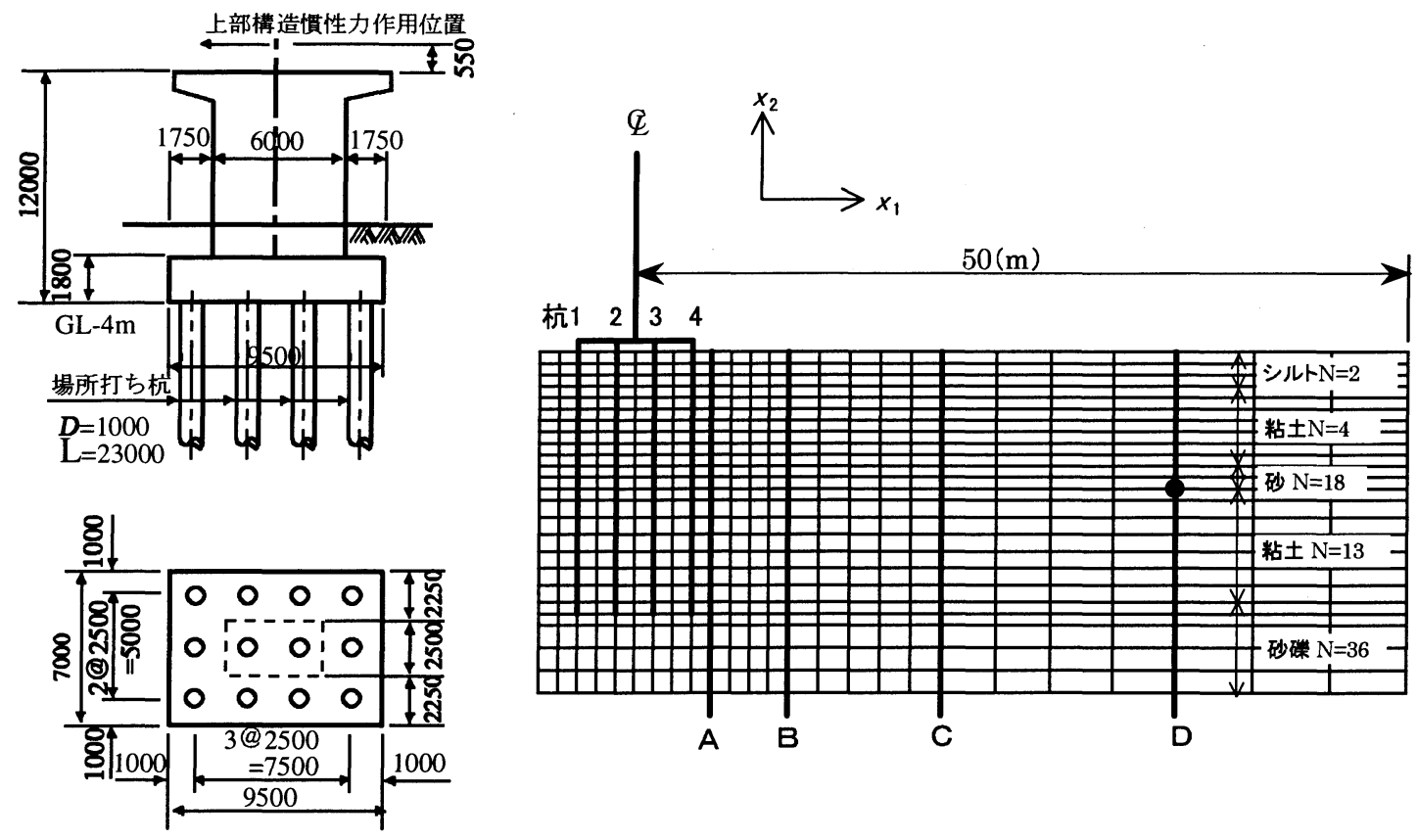

図-19 解析対象橋梁 ${ }^{27)}$ と有限要素メッシュ

後, 精度を高めるには, 座屈発生条件の設定が重要であ り, 特にかぶりコンクリートの応力停留域や，低下勾配 のモデル化が課題である.

\section{5. 杭基礎の地震時挙動解析}

橋脚・杭基礎・地盤一体系での動的解析を行い，提案 モデルの動的解析への適用性を調べるとともに, kinematic interaction の影響も含めた，杭基礎の地震時挙動 を把握する.ここでは, 地盤変位により生じた地中深部 での曲げ損傷が，上部構造の応答に与える影響に着目す る. 解析は, 微小変位理論の枠内で定式化された有限要 素法による.

解析対象は, 道路橋示方書にしたがった既往の設計計 算例 27$)$ の道路橋の橋脚である. 図-19に，橋脚・杭基礎 諸元と有限要素メッシュ (実際は左右対称) を示す. 基礎 は, 道路橋示方書 Vにおける III 種地盤に支持されてお り, 直径 $1000 \mathrm{~mm}$ の場所打ち杭基礎である. フーチン グ底面位置が耐震設計上の地盤面であり GL-4m であ

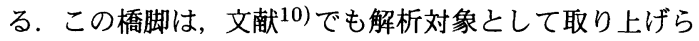
れており, 本解析モデルは, そのモデルとほぼ同様にし てある. 表-3に, 解析で設定した地盤条件を示す，道路 橋示方書 V により求まる地盤の固有周期 $T_{G}$ は $0.60 \mathrm{~s}$ と なり，II 種地盤と III 種地盤のちょうど境界にあたるた め, III 種地盤でも比較的良好な地盤と判断される.

解析は橋軸直角方向に対して行う. 解析ケースは 3

\begin{tabular}{|l|c|c|c|c|c|}
\hline & $\begin{array}{c}\text { 表 }-3 \\
(\mathrm{~m})\end{array}$ & 土地盤構成 \\
& 土質 & $N$ 值 & $\begin{array}{c}V_{s 0} \\
(\mathrm{~m} / \mathrm{s})\end{array}$ & $\begin{array}{c}\rho \\
\left(\mathrm{t} / \mathrm{m}^{3}\right)\end{array}$ \\
\hline 第 1 層 & $4 \sim 7$ & シルト & 2 & 130 & 1.6 \\
\hline 第 2 層 & $7 \sim 14$ & 粘士 & 4 & 160 & 1.6 \\
\hline 第 3 層 & $14 \sim 16$ & 砂 & 18 & 210 & 1.7 \\
\hline 第 4 層 & $16 \sim 26$ & 粘士 & 13 & 240 & 1.7 \\
\hline 第 5 層 & $26 \sim 34$ & 砂喽 & 36 & 260 & 2.0 \\
\hline
\end{tabular}

ケースで, 表-4に示す. ケース 1 は, 文献 27$)$ の橋脚 - 杭 基礎諸元をできる限り忠実にモデル化したものである. ケース 2 は, ケース 1 に対して基礎がより厳しい荷重状 態となるように, 橋脚を線形弾性体へ変更, 杭体の鉄筋 量を低减し, さらに, 地中深部で杭体の一部に耐力低下 が生じるように, 基盤入力地震波の加速度振幅を, 試行 錯誤して元波形の 2.2 倍としたものである. また, ケー ス 3 は, ケース 2 の杭先端の押込み力に対する上限值を 無くして, 杭体に生じる軸力が大きくなるようにしたも ので, 基盤地震波の加速度振幅は, これも試行錯誤し, 元波形の 2.0 倍とした. 各ケースの杭体の配筋を表-5に 示す.

地盤をモデル化する要素は, 本解析の目的が, 地盤の 振動変位による杭基礎の損傷と, 全体系の挙動の関係を 定性的に把握することであるため, 簡単のために平面ひ ずみ要素とした． 要素の奥行き幅は，ここでは単純に， 文献10) と同じく, フーチングの奥行き方向幅の 2 倍とし 
表-4 解析ケース

\begin{tabular}{l|c|c|c}
\hline & ケース 1 & ケース 2 & ケース 3 \\
\hline 橋脚基部 & 非線形 & 線形 & 線形 \\
\hline 杭先端押込み & 非線形 & 非線形 & 線形 \\
\hline 杭体配筋 & - & 低减 & 低减 \\
\hline 基盤入力加速度振幅 & $\times 1.0$ & $\times 2.2$ & $\times 2.0$ \\
\hline
\end{tabular}

た，境界条件は，側方は，鈶直固定，水平自由であり， 底面は，鈶直，水平ともに固定である。

また，地盤の構成則は，Hookeの法則を用い，地盤 の非線形特性は, 瞬間のせん断弾性係数を応力履歷に応 じて変化させることで考慮した．図-19に示すようにデ カルト座標系 $x_{1}-x_{2}$ を設定し, Ramberg-Osgood モデ ル28)により $\sigma_{12}$ の履歴に応じて瞬間せん断弾性係数を与 える.ここに， $\sigma_{i j}$ は， Cauchy 応力である.このモデ ルでは, 地盤の強度定数が考慮できないため, 変形が大 きい領域においても応力が増加し続けるモデルとなって いる. したがって，基礎の変位が大きい領域での地盤抵 抗を過大評価してしまう可能性があるが，これに関して は，非線形特性を規定するパラメターの選定や，用いる 非線形モデル自体の選定を検討する必要があり，今後の 課題である。

地盤の初期せん断剛性は, 表-3の $V_{s 0}$ より設定した. また, ポアソン比 $\nu$ は, 土質によらずすべて 0.49 とし た. Ramberg-Osgood モデルの非線形特性を規定する パラメターは, 文献 ${ }^{28)}$ を参考に最大等価減衰定数 $h_{\max }$ より求めた.ここに， $h_{\max }$ は，砂では $0.3 ，$ 粘土では 0.2 を一律に与えた. また, 基準ひずみ $\varepsilon_{r}$ は, 静止土圧 係数を 0.5 として各要素重心位置深度での拘束圧を算定 し，土質と拘束圧に応じて文献29),30)より与えた.

杭体は，本論文で提案するモデル化を適用し，ファイ バー要素でモデル化する．ここで，奥行き 3 本分を $1 つ$ に集約した.

軸方向鉄筋の塑性座屈解析は，3.と同様に行う．帯鉄 筋バネは, 完全弾塑性型のバネを用いて行った結果を用 いることにした. 解析の結果, 最も耐力低下の大きい座 屈モードとなる解析長 (座屈長) は, すべての断面で帯鉄 筋間隔の 3 倍であった. しかし, 動的解析においては, 杭体の要素分割長と地層構成とを合わせる方が取り扱 いが容易であるため, 軸方向鉄筋の長さを $500 \mathrm{~mm}$ とし て, 再度, 解析を行った. 例として, 図-20に, 配筋 c, $\mathrm{d}$ に関して, 解析長 $L$ が $3 s=450 \mathrm{~mm}$ の場合と $500 \mathrm{~mm}$ の場合の載荷点での荷重 - 変位関係を示す. 同じ荷重 に対する変位量の差は, 非常に小さく, この結果は, 配 筋 $\mathrm{a}, \mathrm{b}$ でも同様である，ここで, 断面 $\mathrm{d}$ は, ほぼ一致 しているため一つの曲線に見えている. よって，ファイ バー要素長を $500 \mathrm{~mm}$ とし, その時の軸方向鉄筋の举動 をはらみ出し発生時の鉄筋の軟化則とした. その他の杭
表 -5 杭体配筋

\begin{tabular}{c|c|c}
\hline $\mathrm{GL}(\mathrm{m})$ & ケース 1 & ケース 2,3 \\
\hline$-4.0 \sim-6.0$ & 配筋 $\mathrm{a}$ & 配筋 $\mathrm{c}$ \\
\hline$-6.0 \sim-12.0$ & 配筋 $\mathrm{b}$ & 配筋 $\mathrm{d}$ \\
\hline$-12.0 \sim-18.5$ & 配筋 $\mathrm{c}$ & 配筋 $\mathrm{d}$ \\
\hline$-18.5 \sim-27.0$ & 配筋 $\mathrm{d}$ & 配筋 $\mathrm{d}$ \\
\hline \multicolumn{3}{|c}{} \\
\hline 配筋 & 主鉄筋 & \multicolumn{2}{|c}{ 帯鉄筋 } \\
\hline 配筋 $\mathrm{a}$ & SD295 22-D32 & SD295 D19ctc150 \\
\hline 配筋 b & SD295 22-D32 & SD295 D16ctc150 \\
\hline 配筋 $\mathrm{c}$ & SD295 11-D32 & SD295 D16ctc150 \\
\hline 配筋 d & SD295 11-D22 & SD295 D16ctc150 \\
\hline
\end{tabular}

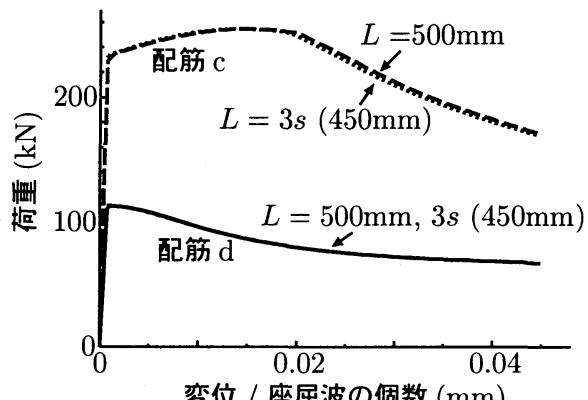

変位 / 座屈波の個数 $(\mathrm{mm})$

図-20 軸方向鉄筋の塑性座屈解析 (配筋 c, d)

体ファイバーのパラメターの設定は，JIS 公称值および 4.の模型杭の解析と同様である。

ここまでのモデル化から, 提案モデルは, 杭体をファ イバー要素によりモデル化しているため, 杭体をはり要 素でモデル化している既存の有限要素メッシュを流用で きるという利点があることがわかる。

杭体と地盤の間は，杭体の要素節点座標と地盤の要素 節点座標が同一の所で，節点間に，水平・鈶直バネを配 置した.

水平バネは, 杭と地盤の水平方向の相対変位, 相対速 度が十分に小さくなるように大きな剛性を設定した線形 のバネである．杭周面に配置される鈶直バネは，地盤と 杭体の周面摩擦力を再現するためのもので, 最大摩擦力 度を上限とする分布バネを節点に集約した完全弾塑性型 の履歴特性を持つバネである. 地盤反力係数は道路橋示 方書 IV のケーソン基礎の設計より，最大周面摩擦力度 は同じく場所打ち杭の設計より，それぞれ $N$ 值に応じ て算出した．杭先端に配置される鈶直バネは，押込み力 には先端支持力を上限とするバイリニア型の抵抗特性を 持ち, 引抜き力には抵抗しない非線形弾性バネである. 地盤反力係数, 極限支持力度の設定は, 周面バネと同様 の考え方で行った.ここでも, 杭周面・先端のばねは, 杭体と同様に奥行き 3 本分を集約して配置した。 ただ 


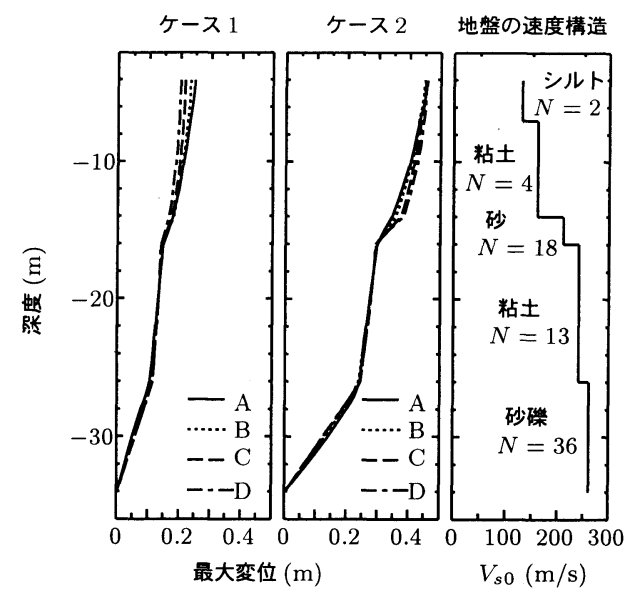

図-21 地盤の最大変位分布

し，上述のように，ケース 3 では，杭先端の押込みに対 する地盤反力度に上限值を設けていない.

橋脚は, ケース 1 では, 基部に, 道路橋示方書 $\mathrm{V}$ に基 づき塑性ヒンジ区間を設定した．塑性ヒンジ区間の曲げ モーメント $M$ - 回転角 $\theta$ 関係は, Takeda モデル ${ }^{31)}$ を与 えた回転バネでモデル化した．ここに，ひび割れ点は無 視し, 降伏点は道路橋示方書 $\mathrm{V}$ より求め, 降伏後剛性は 初期剛性の $1 / 10000$ とした. 基部以外の区間は, コンク リート総断面としての剛性を持つ弾性のはり要素でモデ ル化した．なお，ケース 2,3 では，塑性ヒンジ区間も線 形のはり要素にてモデル化している.

上部構造の質量は, 橋脚頂部に, また, 橋脚の質量 は, 橋脚高の $1 / 2$ の位置に, それぞれ質点としてモデル 化した. フーチングは, 剛なはりでモデル化し, 質量は フーチング重心位置に質点として与えた.

全体減衰行列は, Rayleigh 減衰により与えた。ただ し, 减衰の大部分を地盤の履歴减衰で期待するものと して, 初期剛性を用いて算定した 1 次と 2 次の固有周期 (それぞれ， $0.52 \mathrm{~s}$ と $0.38 \mathrm{~s}$ ) に対して $3 \%$ を設定した. そして, 解析中は, 常に時刻 $t=0 \mathrm{~s}$ の隇衰行列を用い た.ここに, 1 次モードは, 地盤のせん断変形が卓越す るモードであり，地盤と構造物は同位相で変位する．ま た, 2 次モードは, 構造物のロッキング振動が卓越する モードであり, 地盤と構造物は逆位相で変位するもので あった。

道路橋示方書 $\mathrm{V}$ における地盤の固有周期がほぼ $0.6 \mathrm{~s}$ 程度であったことも考え合わせると, 構造物の固有周期 $T_{s}$ と地盤の固有周期 $T_{g}$ の大小関係は, $T_{s}<T_{g}$ と考え られる.

\section{(1) 動的解析結果}

入力地震動は, 兵庫県南部地震 (1995) にて観測され た神戸海洋気象台観測波 NS 成分の主要動 $15 \mathrm{~s}$ 間であ

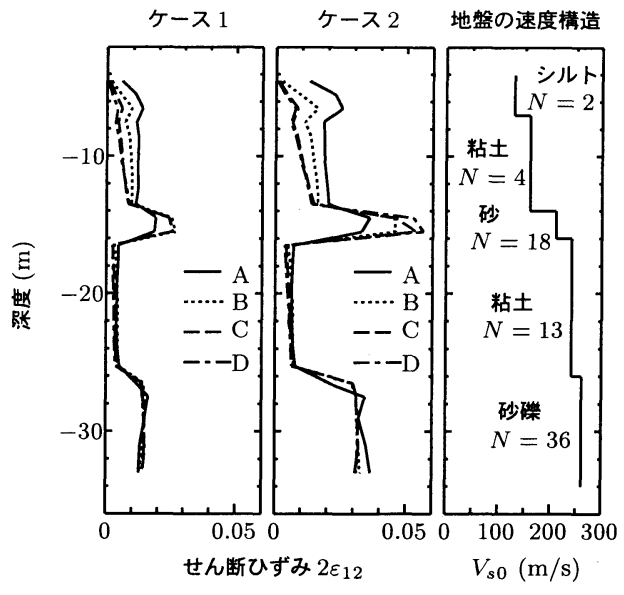

図-22 地盤のせん断ひずみの最大值分布

る. 加速度振幅を所定の倍率にしたものを，地盤の底面 境界から入力した. 解析の結果, ケース 2 と 3 は, ほぼ 同様の挙動を示したため, ここでは, ケース 1 と 2 の結 果を詳しく示す。

\section{a)地盤の挙動}

図-21は地盤の最大変位分布である. A 〜 D は図一 19 の測線に対応している. 以下の図でも同様である.

鉄道構造物の耐震設計標準7)では, 応答変位法に用い る地盤変位分布を算出するために必要な地表面での最大 応答変位を簡便に予測する式が示されている. そこで, ここで対象としている地震動に最も近いと考えられる L2 地震動, スペクトル II の場合の予測式を本解析の地盤 に適用してみると, 約 $0.2 \mathrm{~m}$ となる. 図-21の結果は, ケース 1 では, 耐震設計で考える程度の変位が, ケース 2 では, 設計上, 基礎にとって非常に厳しい変位が生じ ていると考えてよいだろう.

深さ方向にみると, 第 4 首の粘土層から第 3 層の砂層 に入るところで変位が急增し, 第 3 層の砂首から第 2 首 の粘土層に入ると変位振幅の増加は鈍くなる.ここで,

図一22の地盤の最大せん断ひずみ分布を見ると, 第 4 首 の粘土層から第 3 層の砂層に入るとせん断ひずみが急 増しているが，第 3 層の砂層から第 2 首の粘土層に入る とひずみは小さくなっている. 地盤の振動変位分布の 予測や地盤構成と杭の損傷の発生に関して, これまで も研究が行われてきているが, 地盤の振動変位はせん 断波の伝達により生じるものが主であることから, 地 盤の $V_{s 0}$ 比をパラメターに整理を行うことが一般的であ る.ここでも, 地盤の変位分布に関して, 同様の整理を 行ってみると, 第 4 層と第 3 層の初期せん断波速度 $V_{s 0}$ の比は 0.88 , 第 3 層と第 2 首の $V_{s 0}$ 比が 0.76 であり,

第 3 層と第 2 層の $V_{s 0}$ 比の方が小さい. $V_{s 0}$ 比の観点か ら見ると，比が小さい場合の方がせん断ひずみが急增す 


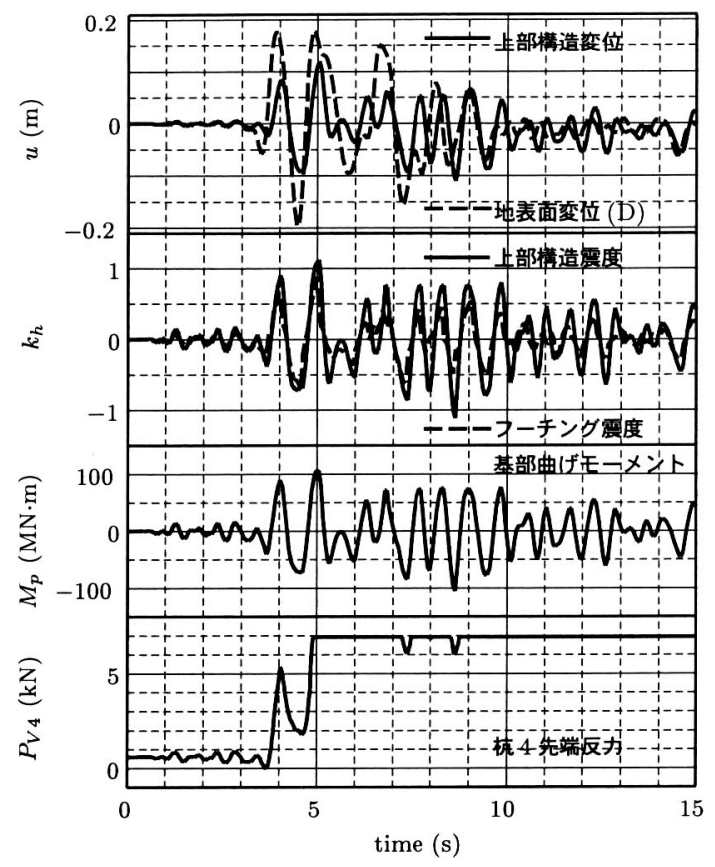

图-23 測線 $\mathrm{D}$ 地表面変位 $u_{g} D s$, 上部構造水平変位 $u_{u}$, 上部 構造震度 $k_{h u}$, フーチング震度 $k_{h f}$, 橋脚基部曲げモー メント $M_{p}$, 杭 4 先端反力 $P_{V 4}$ の時刻歴 (ケース 1$)$

ることになるが，ここでの結果は逆である．これは，砂 質土と粘性土の非線形特性の違いにあると考えられ，レ ベル 2 地震動下における地盤の振動変位分布や, 地盤構 成と杭の損傷度の関倸を整理する際には， $V_{s 0}$ 比に加え て，土質の違いも考慮する必要があると考えられる.

また，図-21，22において，それぞれの分布形状に関 して測線間の比較をしてみると, 地表面付近では応答が 異なり， $15 \mathrm{~m}$ 程度より深いところでは違いが少なくな る.これは, 地表面付近では, 杭の変位は, 地盤変位の 影響だけではなく上部構造慣性力による影響も受けてい るためと考えられ, また, 地中深部においては, 杭の変 位は, 地盤変位の影響によるものが主であることを示唆 しているものと考えられる.

\section{b）基礎の挙動と損傷 : ケース 1}

図-23に, 測線 D の地表面の水平変位, 上部構造慣性 力作用位置の応答, フーチング重心位置の応答, 橋脚 基部の曲げモーメント, 杭 4 先端反力の時刻歴を示す. ここに, 震度は, 水平応答加速度を $-9.8 \mathrm{~m} / \mathrm{s}^{2}$ で除した ものであり, また, 杭 4 先端反力は, 押込み侧が正であ る. 図-23より, 上部構造, 地表面, およびフーチング は，ほぼ同位相で振動していることが分かる．それぞ れ, 絶対值に関して最大值を取った時刻は, 測線 D 地表 面での変位が $4.5 \mathrm{~s}$ ，上部構造の震度が $5.04 \mathrm{~s}$, 橋脚基部 曲汭モーメントが $5.04 \mathrm{~s}$ であり, また, 杭先端での押込

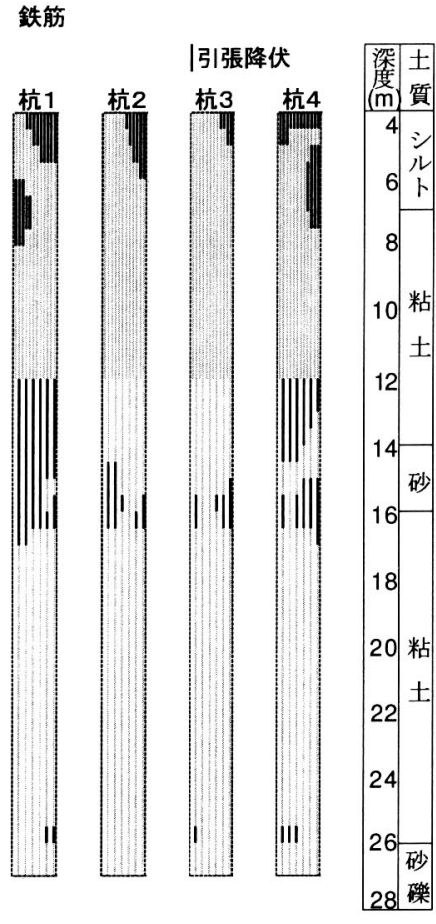

图-24 杭体鉄筋の降伏状況 (ケース 1)

み反力が上限値に達した時刻は $4.9 \mathrm{~s}$ であった. よって, 本解析では, 上部構造に生じる震度の最大值と地表面で の地盤変位の最大值は, 同時に生じているわけではない が, 上部構造の震度が最大の時刻の地盤変位は, ほぼ最 大値に等しいものとなっており, 慣性力と地盤変位の最 大值が同時に基礎に作用したと見てよい.

次に解析終了後の損傷状態について述べる. まず，橋 脚基部であるが，曲げモーメントが最大になるときに， わずかな時間，塑性域に入るが，それ以外では，弾性挙 動をしていた．また，このときの上部構造慣性力作用位 置での応答変位塑性率は 1.34 であった. したがって, 基 礎の挙動の評価にあたっては, 橋脚は弾性挙動をしてい たものと見なして良いと考えられる.

杭体では, かぶりコンクリートは, 引張りによるク ラックが, 全杭で, ほほすずての領域に入っているも のの, 圧縮側では, 圧壊した領域は無かった。したがっ て，鉄筋のはらみ出しは生じていない，

鉄筋に関して, 引張り降伏が生じた位置を, 図-24に 示す．色の薄い線は，鉄筋位置を示している．杭頭部付 近では，全杭で降伏が生じている，また，地中部におい ても, 第 3 層の砂層と第 4 層の粘土首の境界部で, 境界 より上下に杭径程度の範囲で引張り降伏領域がみられ る. また, 支持首の上面位置でも, 多少, 降伏領域がみ られる. つまり, 地中部では, 地盤に発生するせん断ひ 


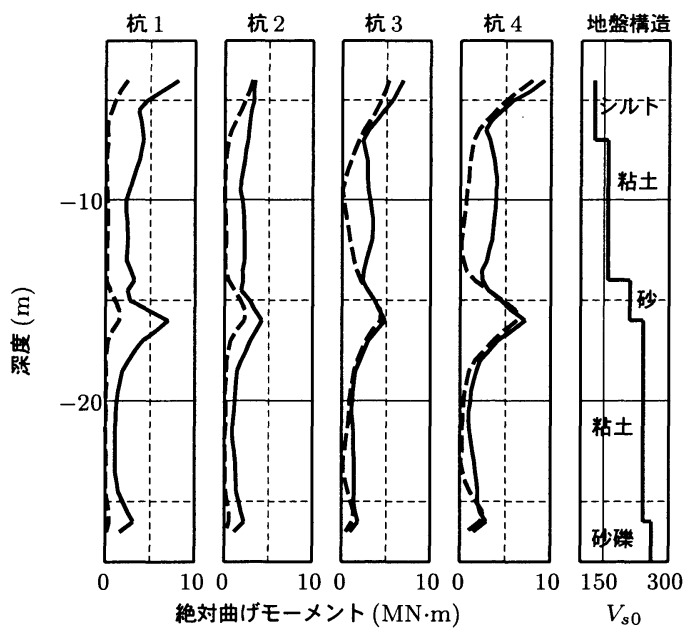

图-25 杭の曲げモーメント分布 (ケース 1): 実線は最大值, 破線は杭 4 先端の押込み力が最大值に達した時刻 $(t=$ $4.9 \mathrm{~s})$

ずみが急変する地層間の境界部で損傷が生じている.

ここで, 第 2 層と第 3 層の境界部でも, 鉄筋の降伏が 見られるが，この位置では，図-21から分かるように， 地盤変位は急増していない.この位置の降伏は，地盤変 位の影響だけではなく, 鉄筋の段落としによる杭の剛 性・耐力の変化が原因と考えられる.

また, 杭頭付近の降伏位置は, 杭位置や, 同じ杭体で あっても内側と外側とで差があるが, 地中部 GL-16m 付近では，同じ杭体でも内側と外側とであまり差がな い.これは，杭頭部では上部構造の慣性力が， GL- $16 \mathrm{~m}$ 付近では地盤変位の影響が，支配的な損傷要因であった ことを示していると考えられる.

一方，圧縮降伏は，軸力が大きかったと考えられる， 最外杭である杭 1,4 の杭頭部内側, および杭 4 の GL$16 \mathrm{~m}$ 付近の外側で生じていた

図-25は，杭体の曲げモーメントについて，杭 4 先端 の押込み反力が最大に達した時刻 $(t=4.9 \mathrm{~s})$ における 絶対值の分布と, 履歴中の絶対值での最大值分布に関し て比較したものである，履歴中の最大值分布 (実線) に着 目すると，全ての杭で，杭頭部と，第 3 層の砂層と第 4 層の粘土層の境界で大きな曲げモーメントが発生してい る.この曲げモーメントの発生位置は, 図-21, 22 に示 すように，地盤の変位・ひずみが急増している部分であ ることから, 地盤の振動変位の作用によるものと考えら れる. また，この結果は，地盤だけの動的解析をパラメ トリックに行い，解析結果を整理することにより，本論 文のように杭基礎 - 地盤系の動的解析を行わずとも, 地 盤の速度構造，土質より，地中部で杭体が損傷を受ける 位置を簡便に推測できる可能性を示している.

4.(2)の実験結果からも分かるように, 杭体に発生す

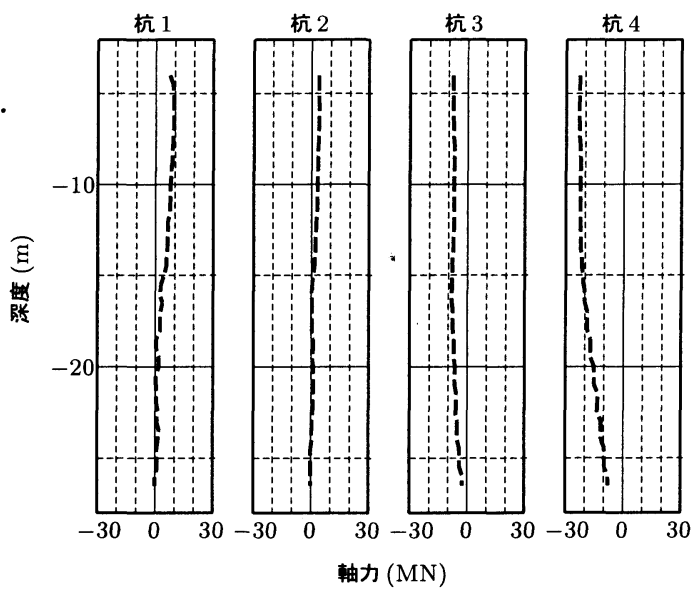

図-26 杭 4 先端の押込み力が最大值に達した時刻 $(t=4.9 \mathrm{~s})$ における杭体の軸力分布 (ケース 1): 引張りが正

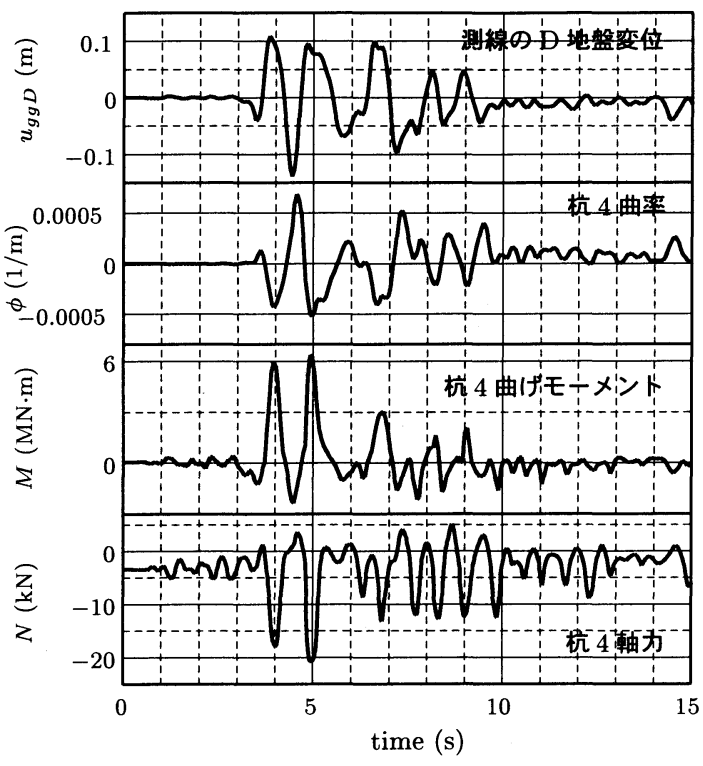

図-27-16m における測線 D の地盤の水平変位 $u_{g g D}$ と杭 4 の曲率 $\phi$, 曲げモーメント $M$, 軸力 $N$ の時刻歴 (ケー ス 1)

る曲げモーメントは, 曲げ変形だけではなく, 軸力にも 依存する. そこで, 杭 4 先端の押込み反力が最大になつ た時刻の曲げモーメント分布 (破線) を見ると，杭 1,2 では，ほとんど曲げモーメントが発生していないことが わかる.図-26は，杭 4 の杭先端押込み反力が最大に達 した時の各杭の軸力分布であるが, これも, 杭 4 以外は 非常に小さい，図-27に，GL-16m における測線 D の 地盤水平変位 (図-19の○点) と, GL-16.25m における 杭 4 の軸力, 曲げモーメント, 曲率の時刻歴を示す. 文 

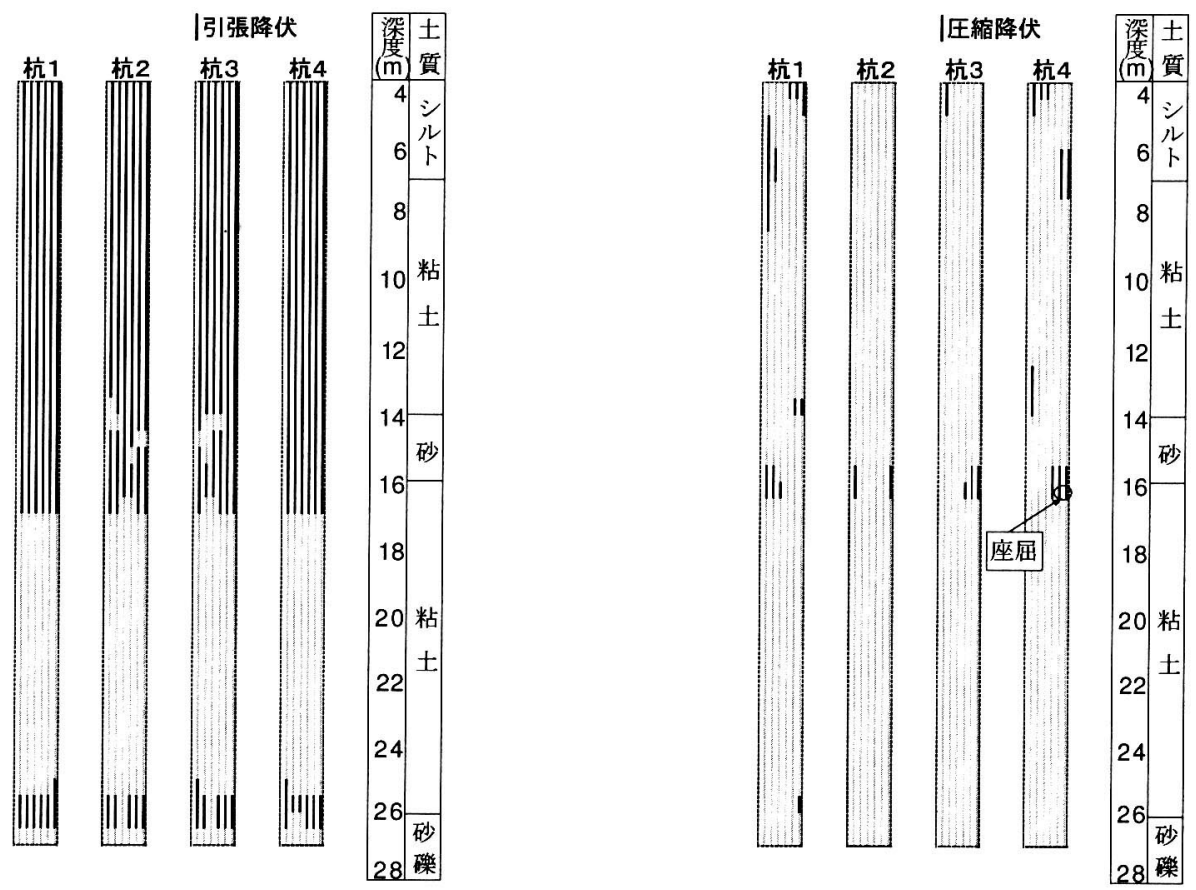

図-28 杭体鉄筋の降伏状況 (ケース 2)

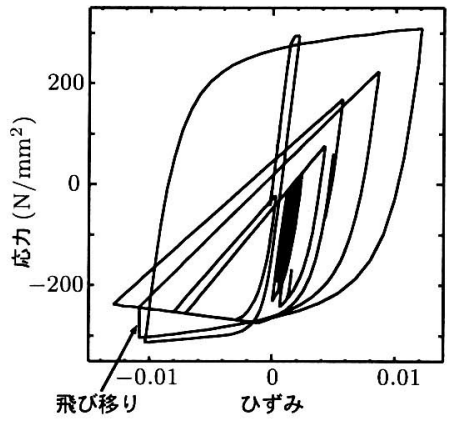

最外緑鉄筋

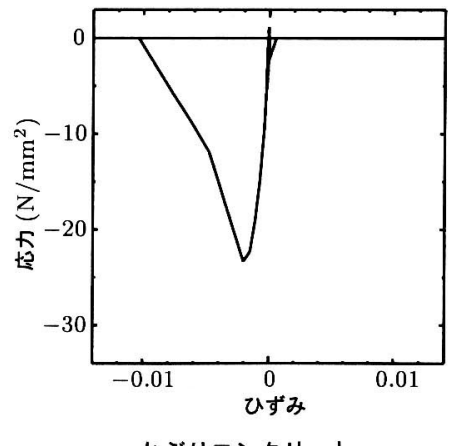

かぶりコンクリート

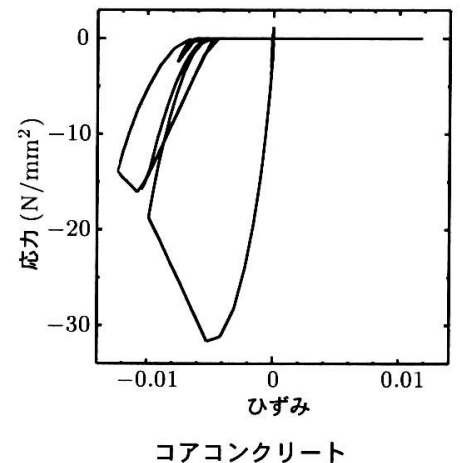

コアコンクリート

図-29 鉄筋のはらみ出しが生じた要素の応力 -ひずみ履歷

献10)でも指摘されているように, 杭体の発生曲げモーメ ントは, 杭体軸力の履歴に依存しており, 地盤変位は, 正負の両者でほぼ同じ最大振幅が生じているが, 発生 曲げモーメント, 曲率は, 杭体の軸力の影響を受けるた め, 正負で同じ大きさの最大振幅とはならない.このよ うに, ファイバー要素による解析では, 利点として, 軸 力変動の考慮が自動的になされることがわかる.

c) 基礎の挙動と損傷 : ケース 2,3

図-28は，ケース 2 の解析に打ける損偒状態である. これも, 色の薄い線は鉄筋位置を示している.ケース 2 では, ケース 1 に比べ鉄筋量を隇じたため, 杭頭部から 地中深部にかけて広い範囲で鉄筋が降伏している.ま
た, ケース 1 でも損傷を受けていた部位である杭 4 の第 3 層と第 4 層の境界部では, 杭頭部よりも大きな損傷を 受けており，かぶりコンクリートの圧壊にともなう鉄筋 のはらみ出しが生じている.この損傷状態は, ケース 3 でも同様であった.

はらみ出しが発生した要素の最外縁軸方向鉄筋の応 力-ひずみ履歴, および, その直近のかぶりコンクリー ト，コアコンクリートの応カーひずみ履歴を图-29に示 す、また，图-30に，はらみ出しが発生した要素のモー メントー曲率関係を示す．杭体は，ケース 1 の結果で考 察したように, 地中部で地盤の振動変位の影響により瞬 間的にはらみ出しが生じるような損傷を受けているが, 


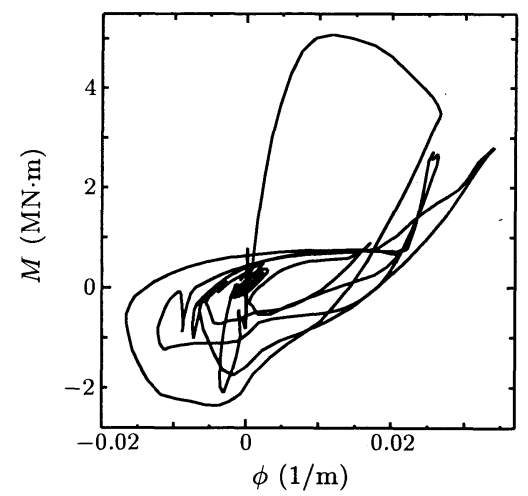

図-30 鉄筋がはらみ出した要素の曲げモーメント $M$-曲率 $\phi$ 関係

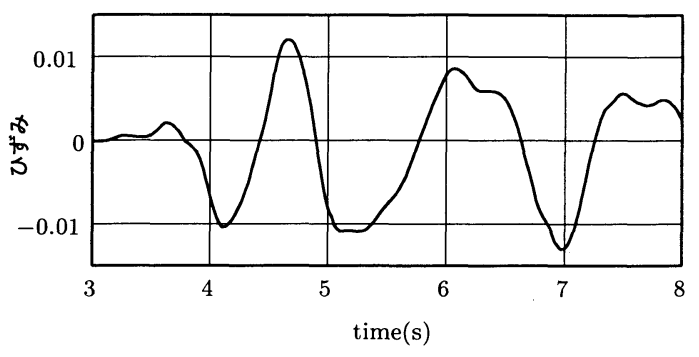

図-31 はらみ出した鉄筋のひずみ履歴 $(3 \mathrm{~s} \sim 8 \mathrm{~s})$

はらみ出しによって著しく耐力が低下するような損傷に は至っていないと判断される.

また，図-29より，鉄筋の応力ーひずみ関係の圧縮側 の経路において, 鉄筋のはらみ出しに伴い, 応力ーひず み履歴に飛び移りが生じていることがわかる.この原 因を明らかにするために，図-31に示すように，はらみ 出した鉄筋の $3 \mathrm{~s} \sim 8 \mathrm{~s}$ の間のひずみの時刻歴を調べてみ た．鉄筋のはらみ出しは, 2.(2)で設定したように, 鉄 筋が, かぶりコンクリートの圧壊ひずみを経験した後, 除荷を受け, さらに圧縮再載荷を受けたときから発生可 能となる．鉄筋のひずみが，かぶりコンクリートの圧壊 ひずみ $\left(\varepsilon_{L}=0.01044\right)$ を越えるのは, $5 \mathrm{~s}$ 過ぎに大きな 圧縮ひずみが生じたときであるが，その直後に，微小な ひずみの振動が生じていることがわかる.したがって, 鉄筋の応力 -ひずみ履歴の圧縮側経路に見られる飛び移 りは，鉄筋が，かぶりコンクリートの圧壊ひずみを経験 した直後に, 微小な除荷・再載荷を受けたために生じた もので, 提案モデルは, このような荷重履歴を受けたと きに，応力が滑らかに遷移するモデルになっていないこ とがわかる.このような荷重履歴に関しては, 実験結果 はなく, 実際に飛び移りのような挙動が生じるかは不 明である. しかし, 後述のように, これが数值的な不安 定を引き起こしている可能性もあり, 改良が必要な点で ある. また, このような微小な除荷・再載荷の発生は,

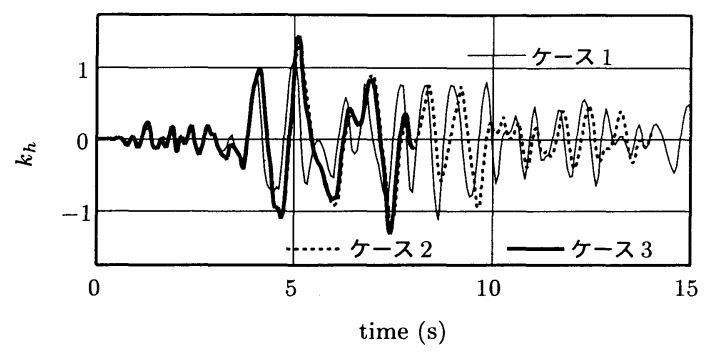

図-32 上部構造震度の比較 : ケース $1,2,3$

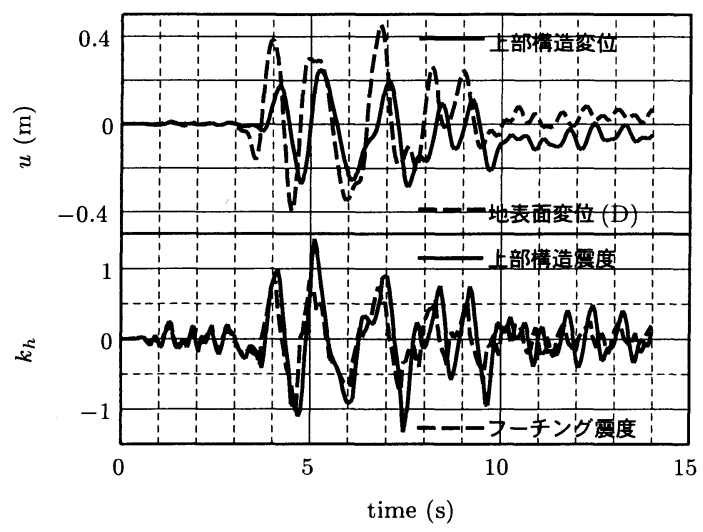

図-33 測線 D 地表面の応答変位 $u_{g s D}$, 上部構造の水平変位 $u_{u}$, 上部構造震度 $k_{h u}$, フーチング震度 $k_{h f}$ の時刻歴 (ケース 2)

堺・川島 ${ }^{32)}$ が指摘しているファイバー要素を用いた場合 の特性とも考えられ, その方面からの検討も, 今後, 必 要であろう.

地中深部での比較的大きな損傷が, 構造物の挙動に与 えた影響を調べるため，图-32に，ケース 1, 2, 3 の上部 構造の応答波形の比較を, 図-33には, 上部構造の応答 と, 測線 D の地表面の応答, およびフーチングの応答の 比較を整理した.

図-32を見ると，ケース $2 ， 3$ は，5s 付近で最大応答 を経験した後, 広い範囲にわたる杭の塑性化によりケー ス 1 より長周期化している. また, 図-33より, ケース 2 では, 特に $8 \mathrm{~s}$ 以後は, 上部構造と地表面の応答の位相 差が大きくなっている. これは, 表層部の杭体に損傷が 生じ, 構造物が長周期化したために $T_{s}$ と $T_{g}$ が近づいた ためと考えられる ${ }^{8), 9)}$.

図-34に，ケース 1 とケース 2 の上部構造の慣性力作 用位置での応答震度 - 応答変位曲線を示す. 地中深部で 杭体の耐力低下が生じているのにもかかわらず，基礎は 十分な復元力を有しており, 変位が一方向のみに增加す るような現象は見られない。このような結果になったの は, 周辺地盤が荷重を分担できること, また, 地盤自体 の応答が一方向に変位が累積するようなものではないた 


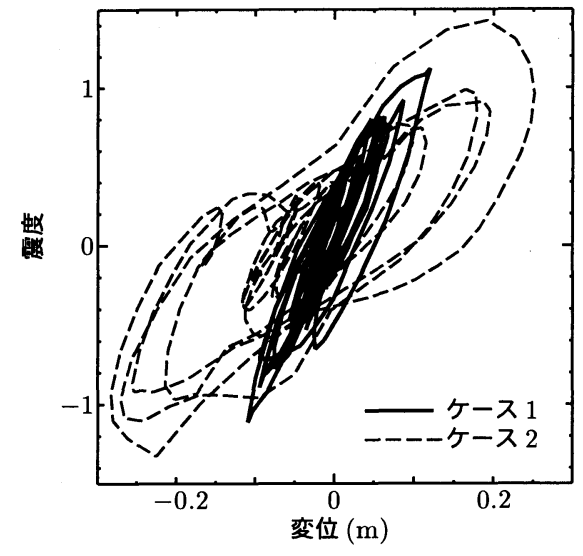

図-34 上部構造の慣性力作用位置での応答震度 - 応答变位曲 線 (ケース 1,2$)$

めに, 鉄筋のはらみ出しが生じた後でも地盤により逆向 きの強制変位を受けることにより, 杭の変形が一方向に のみ大きく增加, 累積しなかったためと考えられる.

図-32で, ケース 2 は $14 \mathrm{~s}$ で, ケース 3 は $8 \mathrm{~s}$ でグラフ がとぎれているが,これは，この時刻で計算が進まな くなったためである. 計算が止まった時刻では, ケース 2,3 のいずれも, 加速度, 変位が非常に小さい領域で あることから，計算が止まったのは，図-29に示したよ うに, 杭体軸方向鉄筋にはらみ出しが発生した際に応力 一ひずみ履歴に不自然な飛び移りが生じたために引き起 こされた数值解析上の収束誤差に起因する問題と考えら れる.したがって，本論文で提案する鉄筋の履歴則を用 いて, 動的解析により杭基礎の地震時限界状態の検討を 行うためには, はらみ出しが発生可能となった直後の微 小な除荷・再載荷履歴を改善する必要があると考えられ る. また, 杭先端バネが線形であるケース 3 がケース 2 よりも早く計算が止まっていることから, 杭先端や杭周 面のバネに減衰特性を見込んでいないことも一因と予測 される.

\section{（2）地震時の地盤の振動変位の影響に対する耐震設計 に関する一考察}

ここでは, (1)の結果より, レベル 2 地震動下におい て生じ得る, 地盤の振動変位による地中深部での損第に 対する耐震設計上の取扱いに関して考察を加える.

本解析結果から, 現行基準による設計諸元と同程度 のじん性を持つ杭体では, 地中部での杭の曲げ破壊によ り, 基礎に過大な変位が生じる可能性は少ないと予測さ れる.

ここで用いている地盤のモデルに関する問題点は既に 述べた通りであるが，これまでの被災事例においても， 地盤に液状化が生じるような場合であっても, 基礎前面
地盤自体に過大な残留変位が生じるなど，原地盤に一方 向への過大な残留変位が生じない場合には，筆者らが把 握する限り，慣性力に対して設計した杭基礎に，落橋を 生じさせるような転倒や著しい変位が生じた事例はな い.

したがって，設計は，慣性力に対して設計した基礎に 対して, 地盤の振動変位の作用を考慮した場合の計算も 行い, 地盤変位により杭体が降伏すると予測される範囲 では, 十分な変形性能を確保すればよいと考えられる。

さらに，設計実務において簡便にこれを考慮すること を考えれば，地盤の振動変位の作用を考慮した設計計算 を行わずとも, 慣性力に起因する水平力, 転倒モ一メン トに対して設計した杭基礎に対して，特に，地層の境界 部から上下に杭径分程度の範囲においては, 断面耐力が 急変しないよう段落としをせず，また，杭体がじん性に 富む構造となるような補強細目を規定しておけばよい と考えられる.これは，(1)の動的解析結果より，杭体 が地中部で損傷を受けると考えられる領域は, 地盤調査 結果から予測可能であると考えられること, また, 地中 深部において，たとえ鉄筋のはらみ出しが生じた場合で あっても, 損傷した杭が軸力・せん断力を伝達すること が可能である場合には, 急激に変位が一方向に増加する ような状態にはならないと予測され, 安全の余裕度を有 していると考えられるためである.ただし，具体的な補 強位置, 適当な補強鉄筋量は, 今後, 動的解析や応答変 位法などによる解析事例を増やすことで同定する必要 があり, 解析事例のこの視点からの整理, 蓄積が望まれ る.

本解析は, 微小変位理論の範囲内であること, 地盤 のモデル化に平面ひずみ要素を用いて, かつ RambergOsgood モデルで非線形性を与えていることから, 基礎 の水平支持に関して有利なモデル化をしている可能性が あり, いわゆる大変位が生じる場合のモデル化という点 では不十分な点である. また, 入力地震波の特性の影響 もあるだろう. 今後, これらの点を検討し, 地中部での 損傷がもっと大きい事例に関して動的解析を行ない, 地 盤の振動変位により地中深部で受ける損傷に対する基礎 としての限界状態を明らかにして行く必要がある.

\section{6. まとめ}

本論文では, まず, 場所打ち杭の弾性挙動から耐力低 下挙動までを解析するための, 鉄筋のはらみ出しを考慮 したファイバー要素によるモデル化手法を提案した. そ して, 載荷実験結果の解析を行ない, 提案モデルの精度 を検証した. 次に, 提案モデルを用いて場所打ち杭基礎 の地震時举動を解析することにより, 提案モデルの動的 解析への適用性を確認するとともに, 地盤の振動変位の 
影響を考慮する場合の場所打ち杭基礎の設計法について 検討した.

提案したモデル化手法は，諸元の異なる杭の繰返し載 荷実駼結果に対して, 実験で見られるような耐力低下挙 動の発生, 損傷の進展を再現できること, また, 動的解 析においても杭体をはり要素でモデル化してある既往の 有限要素メッシュをそのまま使用可能であるという取扱 いの良さから, 場所打ち杭基礎の地震時挙動の解析に有 効な手法であることを示した. しかし，提案手法は，座 屈発生の判定やそれに関連するコンクリートの応力ーひ ずみ関係の荷重保持領域, 低下勾配の設定, また, 座屈 の発生が可能となった直後の鉄筋の履歴則などにまだ改 良の余地がある。

また, 場所打ち杭基礎の動的解析結果は, 地盤に過大 な残留変位が生じず, 杭の水平変位に対する地盤の反力 が期待できる場合には, 地盤の振動変位により地中深部 で杭体に生じる曲げ損傷が, 基礎の復元力に与える影響 は小さいと予測できるものであった. よって,このよう な地盤条件の設計に関しては, 慣性力に対して設計した 杭基礎に対して, 地盤変位作用も考慮した設計も行い, 杭体に所要のじん性を確保すればよいと考えられる. さらに, 設計実務上, 簡便に取扱う方法を考える場合に は, 慣性力の作用に対して設計した杭基礎に対して, 地 層境界部で帯鉄筋により適当な補強を行い, じん性を確 保しておくという構造細目的な取扱いができることを示 した.

しかし, 地盤の振動変位の影響により引き起こされる 損傷により, 上部構造の安全性に影響を与えるような過 大な傾斜や残留変位が生じる場合の限界状態は，なお今 後の検討課題である.

最後になるが，本論文では，杭基礎の地震時の不安定 挙動を把握することを通して設計条件と限界状態を検討 するという, 性能照查型設計法の確立への一つの方を 示せたと考えている. 今後は, 確認された問題点を解決 し, 解析事例を增やし, 杭基礎の耐震性能を明らかにし て行く必要がある.

\section{付録 I 解析コード}

本論文での FEM 解析は, 軸方向鉄筋の塑性座屈解析 および杭載荷実験の解析は, MSC/ABAQUS ver.5.7133)により, また，杭基礎の動的解析は, TDAP III ver.2.0 $0^{34)}$ により，それぞれ必要な構成則をユーザーサブ ルーチンで組込んで行った.

\section{参考文献}

1）日本道路協会：道路橋示方書 V 而震設計編， 1996.

2) 日本道路協会：道路橋示方書 IV 下部構造編， 1996.
3) 木村嘉富, 大越盛幸, 中野正則, 福井次郎, 横山功一: 杭 基䃈の変形性能に関する実験的研究, 構造工学論文集, Vol. 44A, pp. 1597-1606, 1998.

4) 褔井次郎, 中野正則, 木村嘉富, 石田雅博, 大越盛幸, 阪 野彰：杭基礎の変形性能に関する載荷試験, 土木研究所資 料, 第 3553 号, 1998 .

5) 建設省土木研究所：平成 7 年 (1995 年) 兵庫県南部地震災 害調查報告，土木研究所報告，第 196 号， 1996 .

6) 杭基碳耐震問題研究会：地震時の地盤变形が杭の耐震性に 及ぼす影㗽度に関する研究， 2000 .

7) 鉄道総合技術研究所編：鉄道構造物等設計慗準・同解説 耐震設計，丸善， 1999 .

8) Murono, Y. and Nishimura, A.: Evaluation of seismic force of pile foundation induced by inertial and kinematic interaction, 12th WCEE, 2000.

9）室野剛隆，西村昭彦：地盤と構造物の動的相互作用を考慮 した応答変位法，鉄道総研報告，Vol. 13, No. 2, pp. 4146, 1999.

10）立石章, 古池章紀 : 軸力変動を考慮した動的非線形解析に よる杭基礎の耐震性に関する一考察, 第 25 回地震工学研 究発表会講演論文集, pp. 585-588, 土木学会, 1999.

11）前川宏一，土屋智史，福浦尚之：鉄筋コンクリートの非線 形解析の現状と耐震性能照査法の構筑に向けた今後の取り 組み, 第 2 回鋼構造物の非線形数值解析と耐震設計への応 用に関する論文集, pp. 1-16, 土木学会, 1998.

12) Suda, K. and Masukawa, J.: Models for concrete cover spalling and reinforcement buckling of reinforced concrete, 12th. WCEE, No. 1437, 2000.

13) Suda, K., Murayama, Y., Ichinomiya, T. and Shimbo, H.: Buckling behavior of longitudinal reinforcing bars in concrete columns subjected to reversed lateral loading, 11th. WCEE, No. 1753, 1996.

14）中村光：軸方向鉄筋の塑性座屈挙動の解析，コンクリート 構造物の耐震技術 一現状と将来展望一, concrete engineering series 20, pp. 98-100, 土木学会, 1997.

15）中村光, 二羽淳一郎, 田辺忠顕 : 鉄筋の座屈が $\mathrm{RC}$ 構造の ポストピーク挙動に及ほす影響, コンクリート工学年次論 文報告集，Vol. 14, No. 2, 1992

16) Gomes, A. and Appleton, J.: Nonlinear cyclic stressstrain relationship of reinforcement bars including buckling, Engineering Structures, Vol. 19, No. 10, pp. 822-826, 1997.

17）中村光：材料特性としてのコンクリートの応力ーひずみ 関係，コンクリート構造物の耐震技術一現状と将来展望 -, concrete engineering series 20, pp. 92-95, 土木学 会, 1997.

18）富田佳宏 : 有限要素法による大変形弹塑性解析の展望, 塑 性と加工 (日本塑性加工学会誌), Vol. 36 , No. 408, pp. 2-9, 1995

19）白戸真大, 木村嘉富, 福井次郎, 高橋雅裕 : 杭基礎のポ ストピーク挙動に関する一数值解析, 構造工学論文集, Vol. 45A, pp. 1387-1398, 1999. 
20) Menegotto, M. and Pinto, P. E.: Method of analysis for cyclically loaded R.C. plane frames including change in geometry and non-elastic behavior of elements under combines normal force and bending, IABSE symposium on resistance and ultimate deformability of structures acted on by well-defined repeated Loads, Final Reports, Vol. 13, pp. 15-22, Lisbon, 1973

21) Ristic, D., Yamada, Y., Iemura, H. and Petrovski, J.: Nonlinear behavior and stress-strain based modeling of reinforced concrete structures under earthquake induced bending and varying axial loads, Research Report No. 88-ST01, School of Civil Engineering, Kyoto University, 1988.

22）大塚久哲, 星幔順一, 長屋和宏, 村井和彦: 場所打ち杭の 正負交番載荷試験，土木研究所資料，第 3462 号， 1996.

23) Hoshikuma, J., Kawashima, K., Nagaya, K. and Taylor, A. W.: Stress-strain model for confined reinforced concrete in bridge piers, J. of Struct. Eng., ASCE, Vol. 123, No. 5, 1997.

24) 白戸真大, 福井次郎, 木村嘉富 : 場所打ち杭における軸 方向鉄筋のはらみ出し特性に関する数值解析，第 25 回地 震工学研究発表会講演論文集, pp. 569-572, 土木学会, 1999.

25）棚村史郎, 近藤政弘, 金森真, 菅原篤：高強度せ九断補強 鉄筋を用いた模型杭の載荷試験, 鉄道総研報告, Vol. 12, No. 12 , pp. $47-52,1998$.
26）福井次郎, 中野正則, 石田雅博, 七澤利明, 芦達拓哉, 田 口博文：基礎形式の選定手法調查, 土木研究所資料, 第 3500 号, 1996.

27）道路橋設計計算例委員会：実際に役に立つ道路橋の設計計 算例, 土木施工 1998 年 4 月号別冊, pp. 121-141, 山海 堂, 1998.

28）日本建築学会：入門・建物と地盤との動的相互作用, 丸 善, 1996.

29）岩崎敏夫, 龍岡文夫, 高木義和 : 地盤の動的変形特性に関 する実験的研究 II 一広範囲なひずみ領域における砂の動 的変形特性一, 土木研究所報告, 第 153 号, 1980 .

30）岩崎敏夫, 常田賢一, 吉田精一：沖積粘性土の動的変形特 性一せん断剛性率のヒズミ依存性一, 土木研究所資料, 第 1504 号, 1979.

31) Takeda, T., Sozen, M. A. and Nielsen, N. M.: Reinforced concrete responce to simulated earthquakes, J. of the Struct. Div., ASCE, Vol. 96, No. ST12, pp. 2557-2573, 1970.

32）堺淳一，川島一彦：ファイバー要素を用いた鉄筋コンク リート橋脚の地震応答解析, 構造工学論文集, Vol. $45 \mathrm{~A}$, pp. 935-946, 1999.

33) ABAQUS/Standard user's manual, ver. 5.7, Vol. I, II, III.

34) TDAP III 理論説明書, ver. 2.0, 1998.

(2000. 11. 6 受付)

\title{
A MODEL WITH THE SWELLING OUT OF RE-BAR FOR CAST IN PLACE PILE AND ITS APPLICATION TO ESTIMATE THE EFFECT OF KINEMATIC INTERACTION ON PILE FOUNDATION
}

\author{
Masahiro SHIRATO, Yoshitomi KIMURA and Jiro FUKUI
}

We generally suppose for pile foundations under severe earthquakes that some local postpeak regions emerge on pile bodies around the pile top and the boundaries of different soil layers at the ultimate limit state. Experimental results in the past for cast in place RC pile which is the most popular pile type show that the postpeak behavior is caused by the collapse of cover concrete and the swelling out of reinforcement bars. In this paper, we propose a simple constitutive model in which plastic buckling phenomenon is used to describe the swelling out of reinforcement bars in case of applying a fiber element to pile body. Also we use the inherent plastic buckling length of the pile body as the element length. Numerical check applied the proposed model shows an approximate agreement with cyclic loading tests of model piles. Furthermore we execute a dynamic analysis included the present model for a bridge pile foundation and indicate design condition and criteria for kinematic interaction of pile foundations. 